\title{
Choroid Plexus: The Orchestrator of Long-Range Signalling Within the CNS
}

\author{
Karol Kaiser *(1) and Vitezslav Bryja *(1) \\ Department of Experimental Biology, Faculty of Science, Masaryk University, 62500 Brno, Czech Republic \\ * Correspondence: karol.kaiser1@gmail.com (K.K.); bryja@sci.muni.cz (V.B.)
}

Received: 14 June 2020; Accepted: 2 July 2020; Published: 4 July 2020

\begin{abstract}
Cerebrospinal fluid (CSF) is the liquid that fills the brain ventricles. CSF represents not only a mechanical brain protection but also a rich source of signalling factors modulating diverse processes during brain development and adulthood. The choroid plexus (CP) is a major source of CSF and as such it has recently emerged as an important mediator of extracellular signalling within the brain. Growing interest in the CP revealed its capacity to release a broad variety of bioactive molecules that, via CSF, regulate processes across the whole central nervous system (CNS). Moreover, CP has been also recognized as a sensor, responding to altered composition of CSF associated with changes in the patterns of CNS activity. In this review, we summarize the recent advances in our understanding of the $\mathrm{CP}$ as a signalling centre that mediates long-range communication in the CNS. By providing a detailed account of the $\mathrm{CP}$ secretory repertoire, we describe how the CP contributes to the regulation of the extracellular environment-in the context of both the embryonal as well as the adult CNS. We highlight the role of the CP as an important regulator of CNS function that acts via CSF-mediated signalling. Further studies of CP-CSF signalling hold the potential to provide key insights into the biology of the CNS, with implications for better understanding and treatment of neuropathological conditions.
\end{abstract}

Keywords: cerebrospinal fluid; choroid plexus; secretion

\section{Introduction}

A singular feature of the CNS, crucial to its function following neural tube closure and homeostasis throughout adulthood, is the presence ofCSF, which represents the key signalling interface between various distant regions of the CNS. CSF occupies an intricate and interconnected network of ventricles and cavities spanning the whole CNS that collectively give rise to the brain ventricular system. This complex component of CNS architecture consists of four brain ventricles-the paired lateral ventricles, $3 \mathrm{rd}$ ventricle, and 4 th ventricle, that are connected to the central canal of the spinal cord and the subarachnoid space [1]. Preservation of a tubular system filled with CSF as a hallmark of the CNS is characteristic for the whole phylum Chordata [2], including mammals and its evolutionary significance is further highlighted by a similar arrangement consisting of a CNS bathed in a fluid observed even in non-vertebrate organisms such as Drosophila [3].

For most of history, CSF has been assumed to primarily act as a fluid cushion providing mechanistic protection to the brain, an osmotic buffer system, and a route for clearance of metabolic waste and toxic compounds from the brain. This rather narrow view has been recently challenged by the growing evidence pointing to the expanded role of CSF as a conduit for delivery of instructive cues involved in the regulation of multiple aspects of CNS embryogenesis, adult neurogenesis, and modulation of adult brain function [4]. These findings helped to shed new light on the previously-underappreciated capacity of CSF to harbour various bioactive compounds and promote long-range signalling in distinct 
regions of the CNS [5,6], putting into the spotlight distinct parts of the CNS involved in the production of CSF, including the CP [7].

The $\mathrm{CP}$ is a secretory tissue located within each of the brain ventricles that is present in all vertebrates [8]. Considering the strategic position of the $\mathrm{CP}$ in the $\mathrm{CNS}$ and the emerging understanding of its role in the active release of various growth factors and other biologically-active substances into the CSF, the CP has been attracting growing interest as a vital hub orchestrating various aspects of intercellular communication via CSF in both the embryonic and the adult CNS [4,9]. Further solidifying this concept of the $\mathrm{CP}$ acting as a signalling centre, recent findings point to its function as a key entry point for signalling complexes from the blood circulation [10].

In this review, we aim to provide an overview of recent advances regarding the composition of CSF from the standpoint of CP secretome and its multifaceted impact on the regulation of various aspects of CNS embryogenesis and maintenance in adulthood.

\section{CSF-An Intrinsic Component of CNS Environment}

Specific aspects of neural tube development in vertebrates permit early and complete separation of CSF from the surrounding environment, thus allowing for precise regulation of its content early on during embryogenesis [11]. The importance of tight control over CSF composition is evidenced by the rapid acquisition of barrier-like properties in early stages of development by all CNS interfaces in direct contact with CSF, which are thus able to specifically shape and fine-tune CSF content and signalling properties [12,13]. Dynamic changes in the embryonic CSF (eCSF) composition and properties mirror dramatic morphological and functional changes occurring in parallel during CNS development. Upon neural tube closure in mammals, the captured amniotic fluid becomes the nascent CSF. In the ensuing period, preceding formation of the $\mathrm{CP}$, it has been shown that CSF composition correlates to large extent with proteomic changes observed in the developing neuroepithelium $[14,15]$, which displays barrier-like properties [16], enabling regulated release of growth factors and particles from neuroepithelium into the CSF $[17,18]$. Interestingly, the ability of neuroepithelium to tightly control CSF composition in early brain development exhibits interspecies differences, indicating existence of distinct requirements for CSF regulation depending on the complexity of the developing CNS $[19,20]$. In later stages of the embryonic development, the importance of the neuroepithelium as the key site for active regulation of CSF content decreases as it gradually loses its barrier properties [19]. In late embryogenesis, the CP becomes the major site for the production of CSF and the key player in the regulation of CSF proteomic content and capacity to modulate various biological processes in the CNS [21,22]. Even after CP emergence as the predominant source of CSF, the contribution of other CNS domains, such as ependymal cells lining the ventricle and spinal canal, both during embryogenesis and in adulthood, to the production of CSF cannot be discounted [23,24].

Apart from other functions related to the mechanical protection and metabolic turnover, CSF constitutes a signalling environment indispensable for proper growth and functional maturation of the CNS. eCSF has been demonstrated to be crucial for proper execution of genetic programs underlying embryogenesis of various CNS regions as well as control of adult neurogenesis $[25,26]$. A growing list of signalling molecules and growth factors identified in eCSF [5,27], provides compelling evidence explaining the disruption of CNS embryonic development observed as a consequence of CSF removal [28]. Furthermore, obstructing CSF flow has been shown to impede distribution of supramolecular complexes such as lipid particles, thus highlighting additional mechanism through which CSF-dependent distribution of various biologically-active compounds and complexes affects embryonic growth [29]. CSF proteome undergoes age-dependent changes [30], likely reflecting distinct requirements for the signalling molecules in the regulation of proper function of the CNS during embryogenesis and adulthood [6,31]. For example, changes in the levels of CSF-borne factor IGF-II, correlate with the age-matched ability of CSF to promote neural proliferation and survival of neural progenitors [5]. 
In addition to its role as a vehicle for distribution of bioactive molecules, hydrodynamic forces associated with CSF flow establish instructive cues that are able to activate ion channels expressed by adult neural stem cells (NSCs) in direct contact with CSF, which can act as mechanosensory receptors, regulating adult neurogenesis [32]. Interestingly, CSF dynamics change in response to different physiological states such as sleep, implying a possible role of CSF in the coordination of the biological activity across the CNS in response to the altered physiology [33].

The ability of the 4 CSF to reach and affect processes in various regions of the CNS is not limited to the cell populations in direct contact with the ventricular space. Instead of simply being drained into the blood stream via arachnoid villi granulations [34], it has been shown that a substantial amount of CSF enters brain parenchyma along paravascular spaces as a part of a recently-described "glymphatic" system [35]. This allows CSF-borne substances to spread to large number of brain regions not connected to the ventricular system [36]. Moreover, recent findings have shown the capacity of CSF-derived proteins to regulate proliferation in the subgranular zone (SGZ), one of the two main neurogenic niches in the adult brain, highlighting the potential of CSF to directly control biological processes in brain regions considered to lack direct access to the CSF $[37,38]$.

Given the function of CSF as an essential route for the long-range trafficking of factors across the CNS, CSF has been also explored as a potential source for biomarkers providing information allowing for early detection and diagnosis of distinct pathological conditions such as neurodegenerative diseases or various types of brain cancer $[39,40]$.

Taken together, CSF constitutes crucial element of the CNS extracellular microenvironment with increasingly appreciated roles that extend beyond being a simple mechanic buffer or drainage system for the brain metabolism. A flurry of recent discoveries revealed CSF as a signalling nexus distributing and integrating signals, consisting of a wide array of bioactive compounds, within the whole CNS.

\section{The Choroid Plexus-Key Regulator of CSF Production}

The choroid plexus (CP) is a secretory tissue protruding into the lumen of all brain ventricles, namely the lateral ventricle $\mathrm{CP}(\mathrm{LV} \mathrm{CP})$, the 3rd ventricle $\mathrm{CP}$, and 4th ventricle $\mathrm{CP}(4 \mathrm{~V} \mathrm{CP})$, in the form of a sheet of epithelial cells that are in direct contact with the CSF and encapsulate richly-vascularized stroma [22]. Unlike other developing processes, $\mathrm{CP}$ development progresses in a posterior to anterior manner with $4 \mathrm{~V}$ $\mathrm{CP}$ being first to develop, followed by LV CP with 3V CP being last to emerge [7]. The CP arises from progenitor cells, specified early in the development [41], that are distributed along the dorsal midline and rhombic lip in the case of $4 \mathrm{~V} \mathrm{CP}[42,43]$. CP epithelium (CPe), which originates in the neuroectoderm [44], forms a monolayer of polarized cuboidal cells with high expression of various transport proteins indicating robust secretory capacity [45,46]. Signalling from the CPe is instrumental for the induction of differentiation of the underlying $\mathrm{CP}$ mesenchyme and their mutual interaction is further required for proper choroid plexus morphogenesis [47,48]. Moreover, the $\mathrm{CP}$ is populated by additional cell types including immune cells and neurons, indicative of CP functional versatility $[49,50]$.

As such, the $\mathrm{CP}$ represents a complex tissue that fulfils distinct roles essential to the CNS function. Several lines of evidence clearly established the CP as the major site for CSF production [21], despite some controversy still remaining regarding the extent of its contribution [51]. Importantly, ablation of various channel and transporter proteins located at the apical side of the CPe resulted in severe decrease in the CSF production providing compelling evidence for role of the $\mathrm{CP}$ in this process. Furthermore, the $\mathrm{CP}$ has been implicated in the CNS homeostasis via maintenance of CSF pH balance and ion osmoregulation [46]. Along the same lines, the CP actively contributes to the removal of harmful compounds originating from the blood stream or generated by brain metabolism [52,53].

However, the key functional feature of the $\mathrm{CP}$, conferred by the presence of junction proteins in the epithelium [12,45], is the ability of the $\mathrm{CPe}$ to act as a selectively-permeable interface, preventing free passage of compounds between CSF and the blood, thus establishing the blood-CSF barrier (BCSFB) [4]. This functional aspect of $\mathrm{CP}$ biology is essential. Fenestrated capillaries in the CP stroma and substantial local blood flow rate collectively create a highly-permeable environment enabling fast and unhindered 
spread of substances from blood to the CP stroma [54]. Significant protein secretion capacity displayed by $\mathrm{CPe}$ in tandem with selective transport of compounds from the blood stream might explain the differences of proteomic profiles between CSF and blood [55,56]. Due to its convoluted morphology and presence of microvilli on the apical surface, CPe surface area corresponds up to $50 \%$ of the overall luminal area of brain capillaries establishing the blood-brain barrier (BBB) $[57,58]$. Upon their maturation, $\mathrm{CP}$ epithelial cells manifest increased mitochondrial density, thought to provide energy supply for the considerable metabolic demands linked to the secretory activity of the $\mathrm{CPe}[58,59]$.

Despite shared morphology and function, embryonic CPs preserve their specific domain identities. They reflect position of the $\mathrm{CP}$ along the midline axis and underlie distinct transcription signatures and heterogeneous proteomic profiles observed between different embryonic CPs $[49,60]$. Intriguingly, secretome differences revealed across embryonic CPs are suggestive of spatially specific gradients of signalling molecules that lead to the localized activation of downstream signalling pathways within the brain. This site-specific effect of various CP-derived regulators further combines with the compartmentalization of CSF flow within the ventricular system caused by ciliary beating or bodily movements [61]. Indeed, $\mathrm{SHH}$ and Wnt-5a ligands, both selectively enriched in the embryonic $4 \mathrm{~V} \mathrm{CP}$, have been recently linked to the modulation of proliferation and tissue patterning in the adjacent cerebellum [62,63]. Importantly, regionalized proteomic profiles may also underlie morphological differences between individual CPs as they have been implicated in different aspects of tissue morphogenesis such as the maintenance of specific progenitor domain associated with the embryonic 4V CP-derived SHH or control of epithelial branching via action of Wnt-5a [64,65]. In addition, observed molecular heterogeneity is associated not only with embryonic epithelial cells but was identified also in other cell populations of developing CPs including fibroblasts, possibly adding another layer to the complexity and specificity of the CP secretory repertoire [49]. Of interest, domain-specific differences in molecular make-up of CPs are also preserved in adulthood. For example, Sod3 gene expression, encoding a metabolic enzyme, is limited to the adult $4 \mathrm{~V} \mathrm{CP}$, whereas the expression pattern for protein kinase encoded by the Penk gene, is completely reversed [60]. The age-dependent shift in the expression of various genes underlying CP detoxification or CSF production capacity has also been observed [45,52], revealing the dynamic nature of the $\mathrm{CP}$ secretory profile over time. It, however, seems that the importance of CSF-borne bioactive molecules released by CSF gradually decreases with age. This view is supported by the general decline in the CPe gene expression in adulthood and the gradual reduction in the CSF vs. brain tissue ratio $[12,60]$. There have also been recent findings showing suppressed ability of CSF to promote neurogenesis correlated with age-dependent changes in the CP secretome $[5,6]$. Interestingly, secreted protein Klotho associated with significant anti-aging properties is highly expressed by the CP during early development and adulthood and its CSF levels exhibit gradual decrease during aging [66,67]. Overall, it is possible that this altered pattern of CP secretory activity may reflect more general changes in CNS biology at different stages of life.

Another emerging aspect of $\mathrm{CP}$ function is the intrinsic ability to sense and respond to changes in the CSF as well as broader physiological changes. It has been recently shown that the CP expresses genes encoding components of circadian clock machinery, such as Bma1, Per1, and Per2, which allow the $\mathrm{CP}$ to influence activity of the key hypothalamic centre involved in the sleep/wake rhythmicity via secreted signals carried by CSF $[68,69]$. Remarkably, this mode of circadian clock regulation displays sex differences mediated by estrogen signalling [70], which is in line with the previous findings showing sex-based variability in the $\mathrm{CP}$ gene expression profile and proteomic signature [71]. It is noteworthy that it has been recently reported that the CP might be, at least partially, involved in the contextual fear-learning as it exhibits, in some instances, stronger response to stressful stimuli at the levels of gene transcription as compared to the hippocampus. Altered expression of multiple genes encoding secreted molecules such as the putative hormone augurin represent an example [72,73]. Recently, the CP has been also implicated as an entry site for various hormones produced in response to changed physiological state that are present in the blood, thus directly affecting their availability in the brain. For example, expression of the receptor for the peptide hormone leptin in the $\mathrm{CP}$, which 
is involved in the regulation of the fat balance in the body, has been shown to be the limiting step, determining the transport rate of leptin from the blood stream into the CSF [74].

Due to the expression of specific receptors, the $\mathrm{CP}$ has been also shown to respond to the presence of neurotransmitters present in CSF such as serotonin or nicotine, which are able to elicit robust changes in the CP metabolism and transcriptome $[75,76]$. In addition, a recent pioneering study, leveraging a new technique for real-time monitoring of $\mathrm{CP}$ activity allowed characterization of a novel mode of apocrine secretion from the $\mathrm{CPe}$ in response to stimulation via a serotonin receptor agonist [77].

CSF plays an important role as the key modulator of neuroinflammation. CSF contains distinct pools of activated immune cells, which can be enriched in various neurodegenerative diseases such as Alzheimer's disease (AD) [78,79]. Moreover, CSF displays a complex profile of cytokines and chemokines, which changes dynamically in different neuropathological conditions [80,81]. Interestingly, CSF-mediated regulation of neuroinflammatory response is shaped by the glymphatic system that serves as an important route for drainage and active clearance of immunomodulators and immune cells present in the CSF [82]. Given the profound changes of the adult CP transcriptome in response to inflammatory stimuli, the $\mathrm{CP}$ has recently emerged as an active sensor participating in immunosurveillance within the brain that is capable of dramatically altering CSF proteome via active secretion of cytokines or metallopeptidases $[55,83,84]$. The $\mathrm{CP}$ has been also suggested as the primary site for the initiation of CNS inflammation, allowing free passage of immunocompetent cells from the blood into the CP stroma and their ensuing infiltration of the CSF $[77,85,86]$. This process is mediated by the upregulation of locally-secreted factors forming gradients, homing immune cells towards the $\mathrm{CP}$ epithelium, which exhibits disrupted organization allowing their paracellular passage into the CSF [87-89]. Interestingly, upon inflammation, leukocytes present in the CSF can invade the $\mathrm{CP}$, suggesting the possibility of two-way trafficking of immunocompetent cells across the $\mathrm{CP}$ epithelium [90]. Considering the scope of effects associated with the CP-mediated secretion of immunomodulators and its role in the facilitation of leukocyte entry into the brain [91], the CP has been established as a central regulator of neuroinflammatory processes within the brain, raising important questions regarding the immune privilege of the CNS.

By virtue of its strategic location at the centre of the brain ventricular system, possession of barrier-like properties enabling tight control over CSF content, close contact with blood-borne signals, robust secretory capacity, and ability to sense changes in the local environment, the $\mathrm{CP}$ is uniquely poised to act as a master regulator of long-range signalling in the CNS. The CP thus acts as a principal nexus for integration and transmission of signals along the brain-body axis.

\section{The CP-CSF Signalling Axis and Its Key Mediators}

Deciphering the identity of molecular components underlying the diversity of CSF-mediated signalling along with the identification of the key sources of these factors has become undoubtedly one of the most exciting directions pursued in the field of the CSF research [7,92], with important implications for improvement of current therapies focused on brain regeneration [93].

Emerging knowledge of $\mathrm{CP}$ transcriptome and proteome profiles together with growing insight into the CSF content brought into the spotlight the CP as an important source for a plethora of biologically-active compounds found in the CSF at different developmental stages and physiological states $[6,27,60]$. Elucidation of the molecular identity of these substances is crucial for better understanding of the numerous ways through which CSF modulates key biological processes such as proliferation and neuronal viability during both embryogenesis and adulthood [94,95]. The different types of signalling molecules that were shown to be secreted by the CP to the CSF are summarized in Table 1. 
Table 1. List of signalling factors secreted by the choroid plexus (CP).

\begin{tabular}{|c|c|c|c|c|c|}
\hline Molecule & Category & Biological Function & Species & Stage & References \\
\hline ApoE & Apolipoprotein & $\begin{array}{l}\text { Lipid transport, } \\
\text { Alzheimer's disease } \\
\text { (AD) protection }\end{array}$ & Mouse & Adult & [96] \\
\hline ApoJ & Apolipoprotein & $\begin{array}{l}\text { Lipid transport, } \mathrm{AD} \\
\text { protection }\end{array}$ & Mouse & Embryonic & [62] \\
\hline sAPP & Secreted protein & Adult neurogenesis & Mouse & Adult & {$[38]$} \\
\hline Augurin & Hormone & Cell proliferation & Mouse & Adult & [73] \\
\hline BMP-5 & Growth factor & Adult neurogenesis & Mouse & Adult & [6] \\
\hline CT-1 & Growth factor & Gliogenesis regulation & Rat & Adult & [97] \\
\hline FGF2 & Growth factor & $\mathrm{CP}$ embryogenesis & Human, mouse & Embryonic & [98] \\
\hline Hepicidin & Transporter protein & Brain iron homeostasis & Mouse, rat & Adult & [99] \\
\hline IGF-II & Growth factor & $\begin{array}{l}\text { Embryonic } \\
\text { neurogenesis }\end{array}$ & Mouse & Embryonic & [5] \\
\hline IGFBP-2 & Secreted protein & $\begin{array}{l}\text { IGF signalling } \\
\text { regulator }\end{array}$ & Rat & Adult & [100] \\
\hline IL-1 beta & Cytokine & Adult neurogenesis & Mouse & Adult & [101] \\
\hline$\alpha$ Klotho & Secreted Enzyme & Anti-aging effects & Human, rat & Adult & [102] \\
\hline Megalin & $\begin{array}{l}\text { Heparan sulfate } \\
\text { proteoglycan (HSPG) }\end{array}$ & Ligand transport & Human & Adult & [103] \\
\hline Melatonin & Hormone & $\begin{array}{l}\text { Sleep-wake cycle } \\
\text { regulation }\end{array}$ & Rat & Adult & [104] \\
\hline miR-146a & microRNA & Inflammatory response & Mouse & Adult & [105] \\
\hline mIR-204 & microRNA & Adult neurogenesis & Mouse & Adult & [106] \\
\hline NT-3 & Growth factor & Adult neurogenesis & Mouse & Adult & [107] \\
\hline $\begin{array}{l}\text { Homeobox } \\
\text { protein OTX2 }\end{array}$ & Transcription factor & Adult neurogenesis & Mouse & Adult & [108] \\
\hline Semaphorin-3B & Secreted protein & $\begin{array}{l}\text { Neuroepithelium } \\
\text { proliferation }\end{array}$ & Mouse & Embryonic & [23] \\
\hline sFRP-1 & Secreted protein & AD pathogenesis & Human & Embryonic & [109] \\
\hline $\mathrm{SHH}$ & Growth factor & $\begin{array}{l}\text { Cerebellum } \\
\text { development }\end{array}$ & Mouse & Embryonic & [63] \\
\hline Slit-1 & Secreted protein & Adult neurogenesis & Mouse & Adult & [110] \\
\hline Tgm2 & Secreted enzyme & $\begin{array}{l}\text { Embryonic } \\
\text { development }\end{array}$ & Mouse & Embryonic & [111] \\
\hline Transthyretin & Transport protein & Adult neurogenesis & Rat & Adult & [112] \\
\hline Transferrin & Transporter protein & Brain iron homeostasis & Rat & Adult & [113] \\
\hline VEGF & Growth factor & Angiogenesis & Canine & Adult & [114] \\
\hline Wnt-5a & Growth factor & $\begin{array}{l}\text { Cerebellum } \\
\text { morphogenesis }\end{array}$ & Mouse & Embryonic & [62] \\
\hline
\end{tabular}

While the roles for most of these compounds remains unknown, some initial findings indicate their involvement in diverse biological processes. We have previously shown that Wnt-5a, secreted by embryonic $4 \mathrm{~V} \mathrm{CP}$, is able to influence the morphogenesis of the developing cerebellum [64]. Likewise, bone morphogenetic protein 5 (BMP-5), a member of the BMP family of signalling proteins, secreted by the adult LV CP was recently shown to function as a potent activator of adult neurogenesis [6]. By secretion of morphogen antagonists such as Wnt antagonist sFRP-1, CP secretome can further shape and fine-tune the signalling gradient of the growth factors contained in the CSF [109]. In addition to signalling peptides, the $\mathrm{CP}$ functions as source of other types of bioactive molecules, such as transcription factor Homeobox protein OTX2 (OTX2), which has been implicated in the regulation of neuroblast migration and integration of new-born neurons in the olfactory bulb [115]. Remarkably, blocking of the extracellular OTX2 was able to disrupt maturation of parvalbumin inhibitory neurons and expression of plasticity genes in the visual cortex of the adult mouse [116].

Further expanding the array of secreted substances, the $\mathrm{CP}$ has been recently established as the major source of another important class of regulatory molecules contained in the CSF microRNAs [117]. Given its role in the modulation of expression of genes underlying cell cycle progression and differentiation, specific inhibition of the action of microRNA-204 (miR-204) derived 
from CP was linked to the depletion of adult quiescent neural stem cells (qNSC). Another microRNA, miR-128 [118], highly expressed by the CP, has been previously associated with various aspects of differentiation of adult neuronal progenitors [119]. In addition to the $\mathrm{CPe}$, single-cell analysis of the embryonic and adult $\mathrm{CP}$ has demonstrated expression of genes encoding secreted factors, in additional cell types residing in the CP stroma such as fibroblasts expressing Rbp4 or Wisp1, or endothelial cells producing NT3, raising an interesting possibility that these cell subpopulation actively contribute to the spectrum of signalling molecules released from the CP into CSF [49,107].

The $\mathrm{CP}$ is also involved in active transport of various blood-borne molecules, including cerebral transport of various micronutrients such as folate or iron, both essential for proper brain development $[113,120]$. In another example, megalin, a multiligand binding protein, secreted by the CPe has been shown to participate in the transport of IGF1 across the BCSFB and its release into the CSF $[103,121]$.

Further exploration of the ability of the CP to shape CSF content led to recent findings that have established the $\mathrm{CP}$ as the key producer of binding proteins and multimolecular complexes regulating the extracellular transport of various signalling molecules via CSF [122,123]. The wide spectrum and chemical diversity of biologically active molecules (proteins, peptides, small molecules, and nucleic acids) produced by the $\mathrm{CP}$ opened the interesting question about what their cargo in the CSF is. Exosomes and lipoprotein complexes emerged as the most relevant candidate transport mechanisms.

\subsection{Exosomes in CP-CSF Signalling}

Exosomes represent a novel class of membranous extracellular vesicles increasingly recognized for their role as messengers involved in the long-range distribution of various compounds with regulatory functions [124], thus being able to affect a wide array of physiological and pathological processes in various tissues including the brain [125]. Proteomic analysis of CSF clearly shows enrichment of CSF exosomes for $\mathrm{CP}$-specific proteins [126]. Evidence for active release of exosomes by the $\mathrm{CP}$ into the $\mathrm{CSF}$ came from study of the effects of systemic inflammation. Interestingly, $\mathrm{CP}$-derived exosomes contained various miRNAs such miR-146a and miR-155, expressed by the $\mathrm{CPe}$, which were able to cross the ependymal layer and be taken up by astrocytes and microglia in the brain parenchyma [105]. Increased levels of different miRNAs associated with CSF exosomes were also recently identified as biomarkers for various neuropathological conditions such as Parkinson's disease or epilepsy [127,128], indicating that examination of the active secretion of different miRNAs from the CP may provide further insights of the underlying pathophysiology. Moreover, selective inhibition of miRNA expression using novel $\mathrm{CP}$-targeting approaches opens interesting possibilities for further improvements in the treatment of numerous CNS-related disorders [38].

Interestingly, exosomes' cargo varies over time, a process that may contribute to the age-dependent changes in the CNS function [129]. Exosomes were also suggested as a possible extracellular carrier for various signalling factors, as described for $\mathrm{SHH}$ released from embryonic $4 \mathrm{~V} \mathrm{CP}$ into the CSF [130]. Furthermore, exosomes generated by the $\mathrm{CPe}$ were also demonstrated to provide a transport mechanism for distribution of nutrients such as folate within the brain [120]. Moreover, exosomes secreted by the adult $\mathrm{CPe}$ can be hijacked to serve as a vehicle for the spread of virus infection from periphery to the CNS as shown for human polyomavirus (JCPyV) [131]. Intriguingly, CP-mediated release of exosomes may underlie transmission of SARS-coronavirus 2 (SARS-CoV-2) within the CNS as the $\mathrm{CP}$ displays relatively-high expression levels of ACE2 receptor, which is engaged by SARS-CoV-2 for active invasion of host cells [132-135].

\subsection{Lipoprotein Complexes in CP-CSF Signalling}

Lipoproteins represent another important group of extracellular particles produced by the CP [136]. Lipoproteins consist of a lipidic core surrounded by an outer layer that consists of hydrophobic lipids and apolipoproteins, which establish a special class of proteins with scaffolding function [137]. Lately, lipoproteins have been appreciated as being more than mere vehicles for transport of lipids, 
as evidenced by their capacity to carry various bioactive molecules with a central role in brain biology $[138,139]$. First, the $\mathrm{CPe}$ is the site for production of two of the most abundant apolipoproteins present in the CSF, namely apolipoprotein E (ApoE) and ApoJ [96,140-142]. Moreover, the CP was recently identified as the main entry point for lipoproteins containing ApoA-1 from the blood stream into the CNS [10]. Further, central components of molecular machinery underlying lipoprotein biogenesis, ABCA1 and ABCG1 [143], are expressed in the CP both in the embryonic development and in the adulthood $[144,145]$. Interestingly, apolipoprotein distribution varies between species with increased complexity observed in mammalian eCSF compared to avian eCSF, which has been hypothesized to reflect the more intricate neural architecture and synaptic plasticity seen in mammals [146]. Direct comparison of lipoproteins between CSF and blood revealed distinct pattern of posttranslational modifications, that might reflect the distinct functional properties and tissue-specific roles played by lipoproteins [147].

Underscoring the signalling potential of lipoproteins, low-density lipoproteins isolated from eCSF are responsible, to a significant extent, for neurogenic activity of the eCSF [148]. On the other hand, changed levels of high-density lipoproteins in CSF were linked to the pathophysiology of various neurodegenerative diseases [149]. In the recent years, several morphogens produced by the CPe were identified to associate directly with lipoproteins, including SHH [63,150], FGFs [98,151], or Wnts [62]. Moreover, association with lipoproteins, impaired in a mutated version of TREM2 receptor, a risk factor for $\mathrm{AD}$, leads to suppression of lipoprotein-bound $\beta$-amyloid $(\mathrm{A} \beta)$ uptake in the CP $[152,153]$.

Similarly to exosomes, lipoproteins were also shown to incorporate and actively transport miRNAs [154]. Furthermore, CSF lipoproteins are able to harbour proteins that can serve as interacting partners for morphogens, such as the Wnt ligand-binding partner, afamin. [155,156]. Heparan sulfate proteoglycans (HSPGs) represent a class of membrane-bound receptors for various ligands with the ability to shape the growth factor gradient [157], which can be also actively released into extracellular space including CSF [158]. Interestingly, it has been shown that the HSPG protein, glypican, found in CSF can bind directly to lipoprotein particles and contribute to adult neurogenesis $[159,160]$. In addition $\mathrm{SHH}$, a morphogen secreted by the embryonic CP [63], was shown to associate with glypican-bound lipoprotein particles with important functions related to its internalization and signalling [160].

Aside from serving solely as scaffolding proteins for lipoproteins, apolipoproteins recently emerged as regulatory molecules in their own right with importance for the brain function [161]. Interaction of APOE with low-density lipoprotein receptor-related protein 1 (LRP1) was shown to affect differentiation of cortical and spinal cord neural stem cells progenitors [162]. Competition between APOE and tau protein for LRP1 receptor binding, which is involved in AD pathophysiology, has been recently demonstrated as a mechanism for reduction of tau uptake and its subsequent spread within the CNS [163]. ApoJ has been recently proposed as a molecular compound protecting against $A \beta$-mediated induction of $\mathrm{Ca}^{2+}$ influx into neuronal cells probably as a function of the ability of ApoJ to directly bind to A $\beta$ in the CSF $[164,165]$. Moreover ApoJ was revealed to directly interact with Wnt-5a protein released by the CP into the CSF during embryogenesis [62]. On the other hand, decreased CSF levels of ApoA1 were revealed as biomarkers associated with increased risk of neurodegenerative diseases such as $\mathrm{AD}$ [166]. Moreover, intravenous injection of recombinant ApoA1 was shown to efficiently reduce A $\beta$ load in the AD mouse model [167], thus identifying manipulation of CSF apolipoproteins as a promising strategy for future therapeutic applications for brain-related diseases. Thus, apolipoproteins produced by the CP and released into the CSF, tethered to lipoproteins, are linked to various aspects of CNS development, homeostasis, and pathology of neurodegenerative diseases. Nevertheless, it should be noted that a significant portion of the neurogenic effects associated with lipoprotein particle-mediated signalling can be attributed to their role as vehicles for the distribution of various lipid species and maintenance of lipid homeostasis in the brain [136].

\section{The Target Brain Regions of CP-CSF Signalling}

CSF-mediated signalling and neurogenesis are intimately linked processes with fundamental role in the development and homeostasis of the CNS. This is highlighted by the fact that neural 
precursors remain in close contact with CSF throughout life [168]. Neuroepithelium consisting of neuronal progenitors, which segregate to the ventricular zone upon neural tube closure and concomitant ventricular system formation, represent the chief source of cells that will give rise to the entire CNS [169]. Ample evidence collected over the last two decades has clearly established CSF as a crucial signalling component underpinning the key aspects of neuroepithelial behaviour $[5,17,170]$. Signalling factors such as Semaphorin-3B, released by the embryonic $\mathrm{CP}$ were shown to affect orientation of the mitotic spindle and apicobasal polarity, thus controlling division of neural progenitors [23]. Neuronal progenitors are characterized by the presence of sensory primary cilia enabling cells to sense and respond to the instructive cues present in CSF [2]. Several growth factors, including SHH and IGF-I, previously shown to be actively secreted by the CP into CSF $[63,121]$, signal via primary cilia providing a possible mechanism, whereby CSF may directly regulate the fate of neuroepithelial cells [171,172]. Apart from simply regulating differentiation of neuronal progenitors, CSF-transported signalling factors were also shown to function as important local morphogenic regulators driving acquisition of regional identity during brain development [26,173]. Furthermore, molecular heterogeneity linked to CP positional identity, may result in generation of locally-restricted gradients of signalling molecules [62,63], thus contributing to the patterning effect of CSF observed during brain development.

Adult qNSCs, reside in two main anatomically-restricted germinal regions, the subventricular zone (SVZ), localized in the wall of the lateral ventricles, and the SGZ in the hippocampus $[174,175]$. qNSCs residing in the SVZ display multiple features facilitating their capacity to sense and be directly regulated by signals present in the CSF. One of the key morphological hallmarks of qNSCs is the presence of a short apical extension, allowing direct contact with the CSF. Akin to embryonic neuronal progenitors, the apical endings of qNSCs contain a primary cilium allowing these cells to actively sense the composition of the CSF [176]. Consistent with their shared embryonic origin, both neuronal precursors and qNSCs exhibit high levels of vascular cell adhesion molecule-1 (VCAM1) that plays a vital role in qNSC fate determination during embryogenesis and their maintenance in adulthood [101,177]. Moreover, VCAM1 has been shown to play the role of an environmental sensor as it can be upregulated in response to increased CSF levels of interleukin $1 \beta$ and SDF1, which are highly expressed and actively secreted by adjacent LV CP [6,101]. In a similar fashion to that observed during embryonic brain patterning [178], behaviour of the adult stem cell niche can also be modulated by local gradients generated by CP-derived signalling molecules, such as chemorepulsive factor Slit2, which acts as a guidance molecule underlying long-distance migration of neuroblasts from the SVZ to the olfactory bulb [110]. Adding a further layer of complexity, recent advances using single cell analysis revealed not only spatial- but also gender-specific transcriptomic signatures in the SVZ [179]. Interestingly, a regionalized and sex-dependent pattern of expression was also associated with genes encoding various receptors and secreted molecules [179]. Notum, a secreted extracellular suppressor of Wnt ligands, displays SVZ-subdomain-specific expression [180], raising an interesting possibility of spatially-restricted regulation of Wnt pathway activation via localized deactivation of Wnt ligands, which were previously shown to be secreted from the CP into CSF [62,111]. Corroborating these findings, transthyretin (TTR), a thyroid hormone transporter predominantly produced by the CP [112], exhibits a gender-specific role in the control of neurogenesis in the SVZ that is restricted to a specific subdomain of the SVZ [181], which is in line with the gender-based differences in CP-derived TTR levels detected in the CSF $[71,182]$. Molecular heterogeneity linked to the receptor repertoire can be also observed between SVZ and SGZ, indicating intrinsic differences in the sensitivity of adult germinal centres to signalling factors presented via CSF $[183,184]$. This is supported by recent finding showing expression of LRP2, receptor for various morphogens, including BMPs and Wnts that were previously detected in CSF, to be restricted only to SVZ and devoid from SGZ. This was further confirmed by SVZ-specific effects of LRP-2 ablation on the regulation of neurogenesis $[185,186]$. Importantly, it has to be noted that additional cell types residing in the SVZ, but lacking direct contact with CSF, can also be a target of the CSF-borne signalling factors and complexes [105]. All these lines of evidence highlight 
the importance of CSF as a source of signalling factors in the CNS, which is preserved across the whole lifespan of an organism.

\section{Concluding Remarks}

Direct contact between neurogenic brain regions and CSF is the hallmark of CNS biology throughout life. CSF is the chief source of trophic factors and instructive cues underlying the key aspects of embryonic development and CNS patterning. The importance of CSF is also conserved in adulthood, when it plays a key role in the regulation of adult neurogenesis and the perturbation of its content is involved in numerous pathological conditions. Considering major breakthroughs in our understanding of $\mathrm{CP}$ function, it is becoming increasingly evident that the $\mathrm{CP}$ is the major player regulating signalling properties of CSF. This view is further emphasized by a growing list of signalling factors and transporting vesicles either directly produced in the $\mathrm{CP}$ or actively transferred from blood across the $\mathrm{CP}$, which acts as a selective barrier between blood circulation and CSF (summarized in Figure 1). Importantly, these factors and vesicles have been linked to a myriad of aspects of brain biology during development and in adulthood. As a result of age progression, active infections or changes of physiological states, $\mathrm{CP}$ transcriptome and secretome can undergo dramatic changes, thus highlighting the $\mathrm{CP}$ as a vital component involved in the modulation of crucial biological processes. Considering the overarching influence of the $\mathrm{CP}$ as the signalling hub of the brain, the recent emergence of experimental approaches for closer examination and manipulation of various facets of $\mathrm{CP}$ secretory activity promises to shed light on various outstanding challenges facing the field. Virus-based vectors, have been described as an exciting new tool for targeted and highly efficient gene delivery, enabling gene manipulation in the $\mathrm{CP}$ [187] and providing a powerful technique for modulation of CNS biological functions via specific alterations of CP proteome [188]. In addition, there is growing scientific interest in leveraging the potential of exosomes and lipoproteins for brain-targeted drug delivery $[189,190]$. At the same time, organoids have been recently recognized as an interesting model to study development of the CP and CSF production [7,191], as evidenced by presence of functional CP-like structures connected to fluid-filled cavities mimicking the functional CP-CSF interface [192,193]. Given the possibility of genetic manipulation, organoids represent a tractable model for the investigation of the molecular mechanism underlying various pathologies associated with impaired CP secretion and CSF production $[130,194,195]$. Thus, examination of $\mathrm{CP}$ secretory properties using a wide array of newly-developed molecular techniques represents an alluring avenue for future research with important implications for our understanding of brain biology across life and improvement of medical interventions aimed at the underlying causes of various developmental or neurodegenerative conditions.
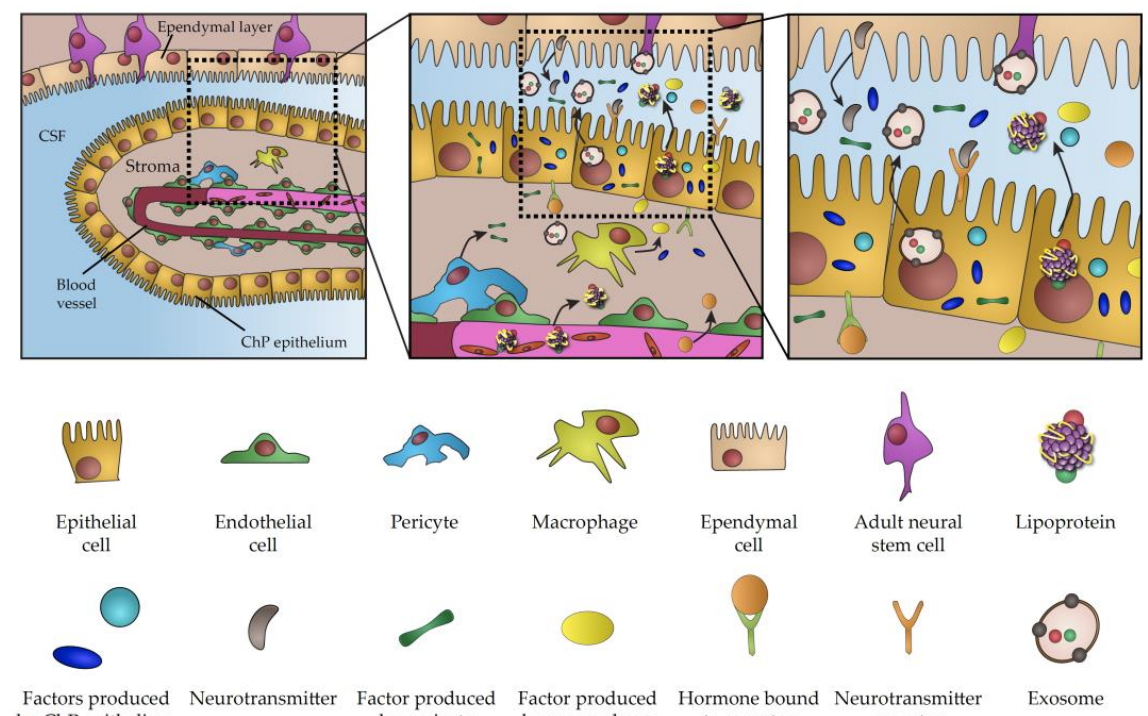

Macrophage
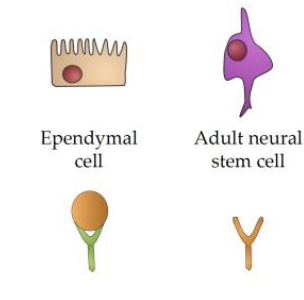

by ChP epithelium
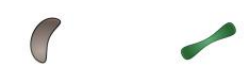

Factor produced by pericyte

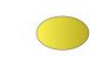

Factor produced by macrophage

Hormone bound Neurotransmitter

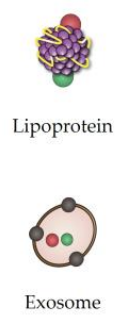

Figure 1. Schematic representation of choroid plexus secretome. 
Author Contributions: Text conceptualization and writing, K.K. and V.B. All authors have read and agreed to the published version of the manuscript.

Funding: This work was supported from European Structural and Investment Funds, Operational Programme Research, Development and Education-Preclinical Progression of New Organic Compounds with Targeted Biological Activity" (Preclinprogress)—CZ.02.1.01/0.0/0.0/16_025/0007381.

Acknowledgments: We thank to Fiona Doetsch and Violeta Silva Vargas for their valuable comments and insights.

Conflicts of Interest: The authors declare no conflict of interest.

\section{Abbreviations}

$\begin{array}{ll}\text { AD } & \text { Alzheimer's disease } \\ \text { ApoE } & \text { Apolipoprotein E } \\ \text { A } \beta & \beta \text {-amyloid } \\ \text { BBB } & \text { Brain-blood barrier } \\ \text { BCSFB } & \text { Blood-CSF barrier } \\ \text { BMP } & \text { Bone Morphogenetic Protein } \\ \text { CNS } & \text { Central nervous system } \\ \text { CP } & \text { Choroid plexus } \\ \text { CPe } & \text { Choroid plexus epithelium } \\ \text { CSF } & \text { Cerebrospinal fluid } \\ \text { eCSF } & \text { Embryonic cerebrospinal fluid } \\ \text { HSPGs } & \text { Heparane sulfate proteoglycans } \\ \text { JCPyV } & \text { Human polyomavirus } \\ \text { LRP1 } & \text { Lipoprotein receptor-related protein 1 } \\ \text { LV CP } & \text { Lateral ventricle choroid plexus } \\ \text { miR } & \text { MicroRNA } \\ \text { NSCs } & \text { Adult neural stem cells } \\ \text { qNCS } & \text { Quiescent adult neural stem cells } \\ \text { OTX2 } & \text { Homeobox protein OTX2 } \\ \text { SARS-CoV-2 } & \text { SARS-coronavirus 2 } \\ \text { SGZ } & \text { Subgranular zone } \\ \text { SVZ } & \text { Subventricular zone } \\ \text { TTR } & \text { Transthyretin } \\ \text { VCAM1 } & \text { Vascular cell adhesion molecule-1 } \\ \text { 4V CP } & \text { 4th ventricle choroid plexus } \\ & \end{array}$

\section{References}

1. Carpenter, E.M. Chapter 2-Development of Brain Ventricles and Choroid Plexus. In The Choroid Plexus and Cerebrospinal Fluid: Emerging Roles in CNS Development, Maintenance, and Disease Progression; Academic Press: San Diego, CA, USA, 2016; pp. 15-27.

2. Fame, R.M.; Cortés-Campos, C.; Sive, H.L. Brain Ventricular System and Cerebrospinal Fluid Development and Function: Light at the End of the Tube. BioEssays 2020, 42, 1900186. [CrossRef] [PubMed]

3. Hindle, S.J.; Munji, R.N.; Dolghih, E.; Gaskins, G.; Orng, S.; Ishimoto, H.; Soung, A.; DeSalvo, M.; Kitamoto, T.; Keiser, M.J.; et al. Evolutionarily Conserved Roles for Blood-Brain Barrier Xenobiotic Transporters in Endogenous Steroid Partitioning and Behavior. Cell Rep. 2017, 21, 1304-1316. [CrossRef] [PubMed]

4. Ghersi-Egea, J.F.; Strazielle, N.; Catala, M.; Silva-Vargas, V.; Doetsch, F.; Engelhardt, B. Molecular anatomy and functions of the choroidal blood-cerebrospinal fluid barrier in health and disease. Acta Neuropathol. 2018, 135, 337-361. [CrossRef] [PubMed]

5. Lehtinen, M.K.; Zappaterra, M.W.; Chen, X.; Yang, Y.J.; Hill, A.D.; Lun, M.; Maynard, T.; Gonzalez, D.; Kim, S.; Ye, P.; et al. The cerebrospinal fluid provides a proliferative niche for neural progenitor cells. Neuron 2011, 69, 893-905. [CrossRef]

6. Silva-Vargas, V.; Maldonado-Soto, A.R.; Mizrak, D.; Codega, P.; Doetsch, F. Age-Dependent Niche Signals from the Choroid Plexus Regulate Adult Neural Stem Cells. Cell Stem Cell 2016, 19, 643-652. [CrossRef] 
7. Fame, R.M.; Lehtinen, M.K. Emergence and Developmental Roles of the Cerebrospinal Fluid System. Dev. Cell 2020, 52, 261-275. [CrossRef]

8. Bill, B.R.; Korzh, V. Choroid plexus in developmental and evolutionary perspective. Front. Neurosci. 2014, 8, 363. [CrossRef]

9. Johansson, P.A. The choroid plexuses and their impact on developmental neurogenesis. Front. Neurosci. 2014, 8. [CrossRef]

10. Stukas, S.; Robert, J.; Lee, M.; Kulic, I.; Carr, M.; Tourigny, K.; Fan, J.; Namjoshi, D.; Lemke, K.; DeValle, N.; et al. Intravenously injected human apolipoprotein A-I rapidly enters the central nervous system via the choroid plexus. J. Am. Heart Assoc. 2014, 3, e001156. [CrossRef]

11. Bueno, D.; Garcia-Fernàndez, J. Evolutionary development of embryonic cerebrospinal fluid composition and regulation: An open research field with implications for brain development and function. Fluids Barriers CNS 2016, 13, 5. [CrossRef]

12. Ghersi-Egea, J.-F.; Babikian, A.; Blondel, S.; Strazielle, N. Changes in the cerebrospinal fluid circulatory system of the developing rat: Quantitative volumetric analysis and effect on blood-CSF permeability interpretation. Fluids Barriers CNS 2015, 12, 8. [CrossRef] [PubMed]

13. Møllgård, K.; Dziegielewska, K.M.; Holst, C.B.; Habgood, M.D.; Saunders, N.R. Brain barriers and functional interfaces with sequential appearance of $\mathrm{ABC}$ efflux transporters during human development. Sci. Rep. 2017, 7, 11603. [CrossRef] [PubMed]

14. Chau, K.F.; Shannon, M.L.; Fame, R.M.; Fonseca, E.; Mullan, H.; Johnson, M.B.; Sendamarai, A.K.; Springel, M.W.; Laurent, B.; Lehtinen, M.K. Downregulation of ribosome biogenesis during early forebrain development. Elife 2018, 7, e36998. [CrossRef] [PubMed]

15. Fame, R.M.; Shannon, M.L.; Chau, K.F.; Head, J.P.; Lehtinen, M.K. A concerted metabolic shift in early forebrain alters the CSF proteome and depends on MYC downregulation for mitochondrial maturation. Development 2019, 146, dev182857. [CrossRef]

16. Møllgård, K.; Balslev, Y.; Lauritzen, B.; Saunders, N.R. Cell junctions and membrane specializations in the ventricular zone (germinal matrix) of the developing sheep brain: A CSF-brain barrier. J. Neurocytol. 1987, 16, 433-444. [CrossRef]

17. Lamus, F.; Martín, C.; Carnicero, E.; Moro, J.A.; Fernández, J.M.F.; Mano, A.; Gato, Á.; Alonso, M.I. FGF2/EGF contributes to brain neuroepithelial precursor proliferation and neurogenesis in rat embryos: The involvement of embryonic cerebrospinal fluid. Dev. Dyn. 2020, 249, 141-153. [CrossRef]

18. Marzesco, A.-M.; Janich, P.; Wilsch-Bräuninger, M.; Dubreuil, V.; Langenfeld, K.; Corbeil, D.; Huttner, W.B. Release of extracellular membrane particles carrying the stem cell marker prominin-1 (CD133) from neural progenitors and other epithelial cells. J. Cell Sci. 2005, 118, 2849-2858. [CrossRef]

19. Whish, S.; Dziegielewska, K.M.; Møllgård, K.; Noor, N.M.; Liddelow, S.A.; Habgood, M.D.; Richardson, S.J.; Saunders, N.R. The inner CSF-brain barrier: Developmentally controlled access to the brain via intercellular junctions. Front. Neurosci. 2015, 9, 16. [CrossRef]

20. Chang, J.T.; Sive, H. An assay for permeability of the zebrafish embryonic neuroepithelium. J. Vis. Exp. 2012, e4242. [CrossRef]

21. Spector, R.; Keep, R.F.; Robert Snodgrass, S.; Smith, Q.R.; Johanson, C.E. A balanced view of choroid plexus structure and function: Focus on adult humans. Exp. Neurol. 2015, 267, 78-86. [CrossRef]

22. Lun, M.P.; Monuki, E.S.; Lehtinen, M.K. Development and functions of the choroid plexus-cerebrospinal fluid system. Nat. Rev. Neurosci. 2015, 16, 445-457. [CrossRef] [PubMed]

23. Arbeille, E.; Reynaud, F.; Sanyas, I.; Bozon, M.; Kindbeiter, K.; Causeret, F.; Pierani, A.; Falk, J.; Moret, F.; Castellani, V. Cerebrospinal fluid-derived Semaphorin3B orients neuroepithelial cell divisions in the apicobasal axis. Nat. Commun. 2015, 6, 6366. [CrossRef] [PubMed]

24. Bátiz, L.F.; Jiménez, A.J.; Guerra, M.; Rodríguez-Pérez, L.M.; Toledo, C.D.; Vio, K.; Páez, P.; Pérez-Fígares, J.M.; Rodríguez, E.M. New ependymal cells are born postnatally in two discrete regions of the mouse brain and support ventricular enlargement in hydrocephalus. Acta Neuropathol. 2011, 121, 721-735. [CrossRef] [PubMed]

25. Alonso, M.I.; Lamus, F.; Carnicero, E.; Moro, J.A.; de la Mano, A.; Fernández, J.M.F.; Desmond, M.E.; Gato, A. Embryonic Cerebrospinal Fluid Increases Neurogenic Activity in the Brain Ventricular-Subventricular Zone of Adult Mice. Front. Neuroanat. 2017, 11, 124. [CrossRef] [PubMed] 
26. Parada, C.; Martín, C.; Alonso, M.I.; Moro, J.A.; Bueno, D.; Gato, A. Embryonic cerebrospinal fluid collaborates with the isthmic organizer to regulate mesencephalic gene expression. J. Neurosci. Res. 2005, 82, 333-345. [CrossRef]

27. Zappaterra, M.D.; Lisgo, S.N.; Lindsay, S.; Gygi, S.P.; Walsh, C.A.; Ballif, B.A. A Comparative Proteomic Analysis of Human and Rat Embryonic Cerebrospinal Fluid. J. Proteome Res. 2007, 6, 3537-3548. [CrossRef]

28. Chang, J.T.; Lehtinen, M.K.; Sive, H. Zebrafish cerebrospinal fluid mediates cell survival through a retinoid signaling pathway. Dev. Neurobiol. 2016, 76, 75-92. [CrossRef]

29. Thouvenin, O.; Keiser, L.; Cantaut-Belarif, Y.; Carbo-Tano, M.; Verweij, F.; Jurisch-Yaksi, N.; Bardet, P.-L.; van Niel, G.; Gallaire, F.; Wyart, C. Origin and role of the cerebrospinal fluid bidirectional flow in the central canal. Elife 2020, 9, e47699. [CrossRef]

30. Baird, G.S.; Nelson, S.K.; Keeney, T.R.; Stewart, A.; Williams, S.; Kraemer, S.; Peskind, E.R.; Montine, T.J. Age-dependent changes in the cerebrospinal fluid proteome by slow off-rate modified aptamer array. Am. J. Pathol. 2012, 180, 446-456. [CrossRef]

31. Chau, K.F.; Springel, M.W.; Broadbelt, K.G.; Park, H.; Topal, S.; Lun, M.P.; Mullan, H.; Maynard, T.; Steen, H.; LaMantia, A.S.; et al. Progressive Differentiation and Instructive Capacities of Amniotic Fluid and Cerebrospinal Fluid Proteomes following Neural Tube Closure. Dev. Cell 2015, 35, 789-802. [CrossRef]

32. Petrik, D.; Myoga, M.H.; Grade, S.; Gerkau, N.J.; Pusch, M.; Rose, C.R.; Grothe, B.; Götz, M. Epithelial Sodium Channel Regulates Adult Neural Stem Cell Proliferation in a Flow-Dependent Manner. Cell Stem Cell 2018, 22, 865-878. [CrossRef] [PubMed]

33. Fultz, N.E.; Bonmassar, G.; Setsompop, K.; Stickgold, R.A.; Rosen, B.R.; Polimeni, J.R.; Lewis, L.D. Coupled electrophysiological, hemodynamic, and cerebrospinal fluid oscillations in human sleep. Science 2019, 366, 628-631. [CrossRef]

34. Davson, H.; Domer, F.R.; Hollingsworth, J.R. The mechanism of drainage of the cerebrospinal fluid. Brain 1973, 96, 329-336. [CrossRef]

35. Iliff, J.J.; Wang, M.; Liao, Y.; Plogg, B.A.; Peng, W.; Gundersen, G.A.; Benveniste, H.; Vates, G.E.; Deane, R.; Goldman, S.A.; et al. A Paravascular Pathway Facilitates CSF Flow Through the Brain Parenchyma and the Clearance of Interstitial Solutes, Including Amyloid $\beta$. Sci. Transl. Med. 2012, 4, 147ra111. [CrossRef]

36. Achariyar, T.M.; Li, B.; Peng, W.; Verghese, P.B.; Shi, Y.; McConnell, E.; Benraiss, A.; Kasper, T.; Song, W.; Takano, T.; et al. Glymphatic distribution of CSF-derived apoE into brain is isoform specific and suppressed during sleep deprivation. Mol. Neurodegener. 2016, 11, 74. [CrossRef]

37. Baruch, K.; Deczkowska, A.; David, E.; Castellano, J.M.; Miller, O.; Kertser, A.; Berkutzki, T.; Barnett-Itzhaki, Z.; Bezalel, D.; Wyss-Coray, T.; et al. Aging-induced type I interferon response at the choroid plexus negatively affects brain function. Science 2014, 346, 89-93. [CrossRef] [PubMed]

38. Arnaud, K.; Moreira, V.O.; Vincent, J.; Dallerac, G.; Le Poupon, C.; Richter, M.; Müller, U.C.; Rondi-Reig, L.; Prochiantz, A.; Di Nardo, A.A. Choroid plexus APP regulates adult brain proliferation and animal behavior. bioRxiv 2020, 734103. [CrossRef]

39. Janelidze, S.; Stomrud, E.; Smith, R.; Palmqvist, S.; Mattsson, N.; Airey, D.C.; Proctor, N.K.; Chai, X.; Shcherbinin, S.; Sims, J.R.; et al. Cerebrospinal fluid p-tau217 performs better than p-tau181 as a biomarker of Alzheimer's disease. Nat. Commun. 2020, 11, 1683. [CrossRef] [PubMed]

40. Miller, A.M.; Shah, R.H.; Pentsova, E.I.; Pourmaleki, M.; Briggs, S.; Distefano, N.; Zheng, Y.; Skakodub, A.; Mehta, S.A.; Campos, C.; et al. Tracking tumour evolution in glioma through liquid biopsies of cerebrospinal fluid. Nature 2019, 565, 654-658. [CrossRef]

41. Thomas, T.; Dziadek, M. Capacity to form choroid plexus-like cells in vitro is restricted to specific regions of the mouse neural ectoderm. Development 1993, 117, 253-262.

42. Currle, D.S.; Cheng, X.; Hsu, C.; Monuki, E.S. Direct and indirect roles of CNS dorsal midline cells in choroid plexus epithelia formation. Development 2005, 132, 3549-3559. [CrossRef] [PubMed]

43. Hunter, N.L.; Dymecki, S.M. Molecularly and temporally separable lineages form the hindbrain roof plate and contribute differentially to the choroid plexus. Development 2007, 134, 3449-3460. [CrossRef]

44. Awatramani, R.; Soriano, P.; Rodriguez, C.; Mai, J.J.; Dymecki, S.M. Cryptic boundaries in roof plate and choroid plexus identified by intersectional gene activation. Nat. Genet. 2003, 35, 70-75. [CrossRef]

45. Liddelow, S.A.; Temple, S.; Møllgård, K.; Gehwolf, R.; Wagner, A.; Bauer, H.; Bauer, H.-C.; Phoenix, T.N.; Dziegielewska, K.M.; Saunders, N.R. Molecular Characterisation of Transport Mechanisms at the Developing Mouse Blood-CSF Interface: A Transcriptome Approach. PLoS ONE 2012, 7, e33554. [CrossRef] 
46. Damkier, H.H.; Brown, P.D.; Praetorius, J. Cerebrospinal Fluid Secretion by the Choroid Plexus. Physiol. Rev. 2013, 93, 1847-1892. [CrossRef] [PubMed]

47. Nielsen, C.M.; Dymecki, S.M. Sonic hedgehog is required for vascular outgrowth in the hindbrain choroid plexus. Dev. Biol. 2010, 340, 430-437. [CrossRef] [PubMed]

48. Wilting, J.; Christ, B. An experimental and ultrastructural study on the development of the avian choroid plexus. Cell Tissue Res. 1989, 255, 487-494. [CrossRef] [PubMed]

49. Dani, N.; Herbst, R.H.; Habib, N.; Head, J.; Dionne, D.; Nguyen, L.; McCabe, C.; Cui, J.; Shipley, F.B.; Jang, A.; et al. A cellular and spatial map of the choroid plexus across brain ventricles and ages. bioRxiv 2019, 627539 . [CrossRef]

50. Prasongchean, W.; Vernay, B.; Asgarian, Z.; Jannatul, N.; Ferretti, P. The neural milieu of the developing choroid plexus: Neural stem cells, neurons and innervation. Front. Neurosci. 2015, 9, 103. [CrossRef]

51. Orešković, D. The controversy on choroid plexus function in cerebrospinal fluid production in humans: How long different views could be neglected? Croat. Med. J. 2015, 56, 306-310. [CrossRef]

52. Kratzer, I.; Strazielle, N.; Saudrais, E.; Mönkkönen, K.; Malleval, C.; Blondel, S.; Ghersi-Egea, J.-F. Glutathione Conjugation at the Blood-CSF Barrier Efficiently Prevents Exposure of the Developing Brain Fluid Environment to Blood-Borne Reactive Electrophilic Substances. J. Neurosci. 2018, 38, 3466-3479. [CrossRef] [PubMed]

53. Saudrais, E.; Strazielle, N.; Ghersi-Egea, J.-F. Choroid plexus glutathione peroxidases are instrumental in protecting the brain fluid environment from hydroperoxides during postnatal development. Am. J. Physiol. Physiol. 2018, 315, C445-C456. [CrossRef] [PubMed]

54. Strazielle, N.; Ghersi-Egea, J.F. Physiology of Blood-Brain Interfaces in Relation to Brain Disposition of Small Compounds and Macromolecules. Mol. Pharm. 2013, 10, 1473-1491. [CrossRef] [PubMed]

55. Thouvenot, E.; Lafon-Cazal, M.; Demettre, E.; Jouin, P.; Bockaert, J.; Marin, P. The proteomic analysis of mouse choroid plexus secretome reveals a high protein secretion capacity of choroidal epithelial cells. Proteomics 2006, 6, 5941-5952. [CrossRef]

56. Guldbrandsen, A.; Vethe, H.; Farag, Y.; Oveland, E.; Garberg, H.; Berle, M.; Myhr, K.-M.; Opsahl, J.A.; Barsnes, H.; Berven, F.S. In-depth Characterization of the Cerebrospinal Fluid (CSF) Proteome Displayed Through the CSF Proteome Resource (CSF-PR). Mol. Cell. Proteomics 2014, 13, 3152-3163. [CrossRef]

57. Keep, R.F.; Jones, H.C. A morphometric study on the development of the lateral ventricle choroid plexus, choroid plexus capillaries and ventricular ependyma in the rat. Dev. Brain Res. 1990,56, 47-53. [CrossRef]

58. Cornford, E.M.; Varesi, J.B.; Hyman, S.; Damian, R.T.; Raleigh, M.J. Mitochondrial content of choroid plexus epithelium. Exp. Brain Res. 1997, 116, 399-405. [CrossRef]

59. Sturrock, R.R. A morphological study of the development of the mouse choroid plexus. J. Anat. 1979, 129, 777-793.

60. Lun, M.P.; Johnson, M.B.; Broadbelt, K.G.; Watanabe, M.; Kang, Y.-j.; Chau, K.F.; Springel, M.W.; Malesz, A.; Sousa, A.M.M.; Pletikos, M.; et al. Spatially Heterogeneous Choroid Plexus Transcriptomes Encode Positional Identity and Contribute to Regional CSF Production. J. Neurosci. 2015, 35, 4903-4916. [CrossRef]

61. Olstad, E.W.; Ringers, C.; Hansen, J.N.; Wens, A.; Brandt, C.; Wachten, D.; Yaksi, E.; Jurisch-Yaksi, N. Ciliary Beating Compartmentalizes Cerebrospinal Fluid Flow in the Brain and Regulates Ventricular Development. Curr. Biol. 2019, 29, 229-241.e6. [CrossRef]

62. Kaiser, K.; Gyllborg, D.; Procházka, J.; Salašová, A.; Kompaníková, P.; Molina, F.L.; Laguna-Goya, R.; Radaszkiewicz, T.; Harnoš, J.; Procházková, M.; et al. WNT5A is transported via lipoprotein particles in the cerebrospinal fluid to regulate hindbrain morphogenesis. Nat. Commun. 2019, 10, 1-15. [CrossRef] [PubMed]

63. Huang, X.; Liu, J.; Ketova, T.; Fleming, J.T.; Grover, V.K.; Cooper, M.K.; Litingtung, Y.; Chiang, C. Transventricular delivery of Sonic hedgehog is essential to cerebellar ventricular zone development. Proc. Natl. Acad. Sci. USA 2010, 107, 8422-8427. [CrossRef] [PubMed]

64. Huang, X.; Ketova, T.; Fleming, J.T.; Wang, H.; Dey, S.K.; Litingtung, Y.; Chiang, C. Sonic hedgehog signaling regulates a novel epithelial progenitor domain of the hindbrain choroid plexus. Development 2009, 136, 2535-2543. [CrossRef] [PubMed]

65. Kaiser, K.; Jang, A.; Lun, M.; Prochazka, J.; Machon, O.; Prochazkova, M.; Laurent, B.; Gyllborg, D.; van Amerongen, R.; Kompanikova, P.; et al. MEIS-WNT5A axis regulates development of 4th ventricle choroid plexus. bioRxiv 2020. [CrossRef] 
66. Vo, H.T.; Laszczyk, A.M.; King, G.D. Klotho, the Key to Healthy Brain Aging? Brain Plast. 2018, 3, $183-194$. [CrossRef]

67. Semba, R.D.; Moghekar, A.R.; Hu, J.; Sun, K.; Turner, R.; Ferrucci, L.; O’Brien, R. Klotho in the cerebrospinal fluid of adults with and without Alzheimer's disease. Neurosci. Lett. 2014, 558, 37-40. [CrossRef]

68. Myung, J.; Schmal, C.; Hong, S.; Tsukizawa, Y.; Rose, P.; Zhang, Y.; Holtzman, M.J.; De Schutter, E.; Herzel, H.; Bordyugov, G.; et al. The choroid plexus is an important circadian clock component. Nat. Commun. 2018, 9, 1062. [CrossRef]

69. Quintela, T.; Sousa, C.; Patriarca, F.M.; Gonçalves, I.; Santos, C.R.A. Gender associated circadian oscillations of the clock genes in rat choroid plexus. Brain Struct. Funct. 2015, 220, 1251-1262. [CrossRef]

70. Quintela, T.; Albuquerque, T.; Lundkvist, G.; Carmine Belin, A.; Talhada, D.; Gonçalves, I.; Carro, E.; Santos, C.R.A. The choroid plexus harbors a circadian oscillator modulated by estrogens. Chronobiol. Int. 2018, 35, 270-279. [CrossRef]

71. Quintela, T.; Marcelino, H.; Deery, M.J.; Feret, R.; Howard, J.; Lilley, K.S.; Albuquerque, T.; Gonçalves, I.; Duarte, A.C.; Santos, C.R.A. Sex-Related Differences in Rat Choroid Plexus and Cerebrospinal Fluid: A cDNA Microarray and Proteomic Analysis. J. Neuroendocrinol. 2016, 28. [CrossRef]

72. Cho, J.; Yu, N.-K.; Choi, J.-H.; Sim, S.-E.; Kang, S.J.; Kwak, C.; Lee, S.-W.; Kim, J.; Choi, D.I.; Kim, V.N.; et al. Multiple repressive mechanisms in the hippocampus during memory formation. Science 2015, 350, 82-87. [CrossRef] [PubMed]

73. Mathew, R.S.; Mullan, H.; Blusztajn, J.K.; Lehtinen, M.K. Comment on "Multiple repressive mechanisms in the hippocampus during memory formation". Science 2016, 353, 453. [CrossRef]

74. Harrison, L.; Schriever, S.C.; Feuchtinger, A.; Kyriakou, E.; Baumann, P.; Pfuhlmann, K.; Messias, A.C.; Walch, A.; Tschöp, M.H.; Pfluger, P.T. Fluorescent blood-brain barrier tracing shows intact leptin transport in obese mice. Int. J. Obes. 2019, 43, 1305-1318. [CrossRef] [PubMed]

75. Lallai, V.; Grimes, N.; Fowler, J.P.; Sequeira, P.A.; Cartagena, P.; Limon, A.; Coutts, M.; Monuki, E.S.; Bunney, W.; Demuro, A.; et al. Nicotine Acts on Cholinergic Signaling Mechanisms to Directly Modulate Choroid Plexus Function. eNeuro 2019, 6. [CrossRef] [PubMed]

76. Conn, P.J.; Sanders-Bush, E.; Hoffman, B.J.; Hartig, P.R. A unique serotonin receptor in choroid plexus is linked to phosphatidylinositol turnover. Proc. Natl. Acad. Sci. USA 1986, 83, 4086-4088. [CrossRef] [PubMed]

77. Shipley, F.B.; Dani, N.; Xu, H.; Deister, C.; Cui, J.; Head, J.P.; Sadegh, C.; Fame, R.M.; Shannon, M.L.; Flores, V.I.; et al. Tracking Calcium Dynamics and Immune Surveillance at the Choroid Plexus Blood-Cerebrospinal Fluid Interface. Neuron 2020. [CrossRef]

78. Liu, Y.; He, X.; Li, Y.; Wang, T. Cerebrospinal fluid CD4+ T lymphocyte-derived miRNA-let-7b can enhances the diagnostic performance of Alzheimer's disease biomarkers. Biochem. Biophys. Res. Commun. 2018, 495, 1144-1150. [CrossRef]

79. Kivisäkk, P.; Mahad, D.J.; Callahan, M.K.; Trebst, C.; Tucky, B.; Wei, T.; Wu, L.; Baekkevold, E.S.; Lassmann, H.; Staugaitis, S.M.; et al. Human cerebrospinal fluid central memory CD4+ T cells: Evidence for trafficking through choroid plexus and meninges via P-selectin. Proc. Natl. Acad. Sci. USA 2003, 100, 8389-8394. [CrossRef]

80. Meeker, R.B.; Poulton, W.; Markovic-Plese, S.; Hall, C.; Robertson, K. Protein changes in CSF of HIV-infected patients: Evidence for loss of neuroprotection. J. Neurovirol. 2011, 17, 258-273. [CrossRef]

81. Kothur, K.; Wienholt, L.; Brilot, F.; Dale, R.C. CSF cytokines/chemokines as biomarkers in neuroinflammatory CNS disorders: A systematic review. Cytokine 2016, 77, 227-237. [CrossRef]

82. Louveau, A.; Herz, J.; Alme, M.N.; Salvador, A.F.; Dong, M.Q.; Viar, K.E.; Herod, S.G.; Knopp, J.; Setliff, J.C.; Lupi, A.L.; et al. CNS lymphatic drainage and neuroinflammation are regulated by meningeal lymphatic vasculature. Nat. Neurosci. 2018, 21, 1380-1391. [CrossRef] [PubMed]

83. Dahm, T.; Frank, F.; Adams, O.; Lindner, H.A.; Ishikawa, H.; Weiss, C.; Schwerk, C.; Schroten, H.; Tenenbaum, T.; Rudolph, H. Sequential transmigration of polymorphonuclear cells and naive CD3+ T lymphocytes across the blood-cerebrospinal-fluid barrier in vitro following infection with Echovirus 30. Virus Res. 2017, 232, 54-62. [CrossRef] [PubMed]

84. Marques, F.; Sousa, J.C.; Coppola, G.; Falcao, A.M.; Rodrigues, A.J.; Geschwind, D.H.; Sousa, N.; Correia-Neves, M.; Palha, J.A. Kinetic Profile of the Transcriptome Changes Induced in the Choroid Plexus by Peripheral Inflammation. J. Cereb. Blood Flow Metab. 2009, 29, 921-932. [CrossRef] [PubMed] 
85. Endo, H.; Sasaki, K.; Tonosaki, A.; Kayama, T. Three-dimensional and ultrastructural ICAM-1 distribution in the choroid plexus, arachnoid membrane and dural sinus of inflammatory rats induced by LPS injection in the lateral ventricles. Brain Res. 1998, 793, 297-301. [CrossRef]

86. Reboldi, A.; Coisne, C.; Baumjohann, D.; Benvenuto, F.; Bottinelli, D.; Lira, S.; Uccelli, A.; Lanzavecchia, A.; Engelhardt, B.; Sallusto, F. C-C chemokine receptor 6-regulated entry of TH-17 cells into the CNS through the choroid plexus is required for the initiation of EAE. Nat. Immunol. 2009, 10, 514-523. [CrossRef]

87. Mottahedin, A.; Joakim Ek, C.; Truvé, K.; Hagberg, H.; Mallard, C. Choroid plexus transcriptome and ultrastructure analysis reveals a TLR2-specific chemotaxis signature and cytoskeleton remodeling in leukocyte trafficking. Brain. Behav. Immun. 2019, 79, 216-227. [CrossRef]

88. Mottahedin, A.; Blondel, S.; Ek, J.; Leverin, A.-L.; Svedin, P.; Hagberg, H.; Mallard, C.; Ghersi-Egea, J.-F.; Strazielle, N. N-acetylcysteine inhibits bacterial lipopeptide-mediated neutrophil transmigration through the choroid plexus in the developing brain. Acta Neuropathol. Commun. 2020, 8, 4. [CrossRef]

89. Strazielle, N.; Creidy, R.; Malcus, C.; Boucraut, J.; Ghersi-Egea, J.-F. T-Lymphocytes Traffic into the Brain across the Blood-CSF Barrier: Evidence Using a Reconstituted Choroid Plexus Epithelium. PLoS ONE 2016, 11, e0150945. [CrossRef]

90. Strominger, I.; Elyahu, Y.; Berner, O.; Reckhow, J.; Mittal, K.; Nemirovsky, A.; Monsonego, A. The Choroid Plexus Functions as a Niche for T-Cell Stimulation Within the Central Nervous System. Front. Immunol. 2018, 9, 1066. [CrossRef]

91. Demeestere, D.; Libert, C.; Vandenbroucke, R.E. Clinical implications of leukocyte infiltration at the choroid plexus in (neuro)inflammatory disorders. Drug Discov. Today 2015, 20, 928-941. [CrossRef]

92. Alonso, M.I.; Gato, A. Cerebrospinal fluid and neural stem cell niche control. Neural Regen. Res. 2018, 13, 1546-1547. [CrossRef] [PubMed]

93. Ren, C.; Yin, P.; Ren, N.; Wang, Z.; Wang, J.; Zhang, C.; Ge, W.; Geng, D.; Wang, X. Cerebrospinal fluid-stem cell interactions may pave the path for cell-based therapy in neurological diseases. Stem Cell Res. Ther. 2018, 9, 66. [CrossRef] [PubMed]

94. Martin, C.; Alonso, M.I.; Santiago, C.; Moro, J.A.; De la Mano, A.; Carretero, R.; Gato, A. Early embryonic brain development in rats requires the trophic influence of cerebrospinal fluid. Int. J. Dev. Neurosci. 2009, 27, 733-740. [CrossRef] [PubMed]

95. Schwarz, N.; Hedrich, U.B.S.; Schwarz, H.; Harshad, P.A.; Dammeier, N.; Auffenberg, E.; Bedogni, F.; Honegger, J.B.; Lerche, H.; Wuttke, T.V.; et al. Human Cerebrospinal fluid promotes long-term neuronal viability and network function in human neocortical organotypic brain slice cultures. Sci. Rep. 2017, 7, 12249. [CrossRef]

96. Xu, Q.; Bernardo, A.; Walker, D.; Kanegawa, T.; Mahley, R.W.; Huang, Y. Profile and Regulation of Apolipoprotein E (ApoE) Expression in the CNS in Mice with Targeting of Green Fluorescent Protein Gene to the ApoE Locus. J. Neurosci. 2006, 26, 4985. [CrossRef]

97. Gard, A.L.; Gavin, E.; Solodushko, V.; Pennica, D. Cardiotrophin-1 in choroid plexus and the cerebrospinal fluid circulatory system. Neuroscience 2004, 127, 43-52. [CrossRef]

98. Greenwood, S.; Swetloff, A.; Wade, A.M.; Terasaki, T.; Ferretti, P. Fgf2 is expressed in human and murine embryonic choroid plexus and affects choroid plexus epithelial cell behaviour. Cerebrospinal Fluid Res. 2008, 5, 20. [CrossRef]

99. Marques, F.; Falcao, A.M.; Sousa, J.C.; Coppola, G.; Geschwind, D.; Sousa, N.; Correia-Neves, M.; Palha, J.A. Altered Iron Metabolism Is Part of the Choroid Plexus Response to Peripheral Inflammation. Endocrinology 2009, 150, 2822-2828. [CrossRef]

100. Tseng, L.Y.; Brown, A.L.; Yang, Y.W.; Romanus, J.A.; Orlowski, C.C.; Taylor, T.; Rechler, M.M. The fetal rat binding protein for insulin-like growth factors is expressed in the choroid plexus and cerebrospinal fluid of adult rats. Mol. Endocrinol. 1989, 3, 1559-1568. [CrossRef]

101. Kokovay, E.; Wang, Y.; Kusek, G.; Wurster, R.; Lederman, P.; Lowry, N.; Shen, Q.; Temple, S. VCAM1 Is Essential to Maintain the Structure of the SVZ Niche and Acts as an Environmental Sensor to Regulate SVZ Lineage Progression. Cell Stem Cell 2012, 11, 220-230. [CrossRef]

102. Olauson, H.; Mencke, R.; Hillebrands, J.-L.; Larsson, T.E. Tissue expression and source of circulating $\alpha$ Klotho. Bone 2017, 100, 19-35. [CrossRef] [PubMed] 
103. Spuch, C.; Antequera, D.; Pascual, C.; Abilleira, S.; Blanco, M.; Moreno-Carretero, M.J.; Romero-López, J.; Ishida, T.; Molina, J.A.; Villarejo, A.; et al. Soluble Megalin is Reduced in Cerebrospinal Fluid Samples of Alzheimer's Disease Patients. Front. Cell. Neurosci. 2015, 9, 134. [CrossRef] [PubMed]

104. Quintela, T.; Gonçalves, I.; Silva, M.; Duarte, A.C.; Guedes, P.; Andrade, K.; Freitas, F.; Talhada, D.; Albuquerque, T.; Tavares, S.; et al. Choroid plexus is an additional source of melatonin in the brain. J. Pineal Res. 2018, 65, e12528. [CrossRef]

105. Balusu, S.; Van Wonterghem, E.; De Rycke, R.; Raemdonck, K.; Stremersch, S.; Gevaert, K.; Brkic, M.; Demeestere, D.; Vanhooren, V.; Hendrix, A.; et al. Identification of a novel mechanism of blood-brain communication during peripheral inflammation via choroid plexus-derived extracellular vesicles. EMBO Mol. Med. 2016, 8, 1162-1183. [CrossRef] [PubMed]

106. Lepko, T.; Pusch, M.; Müller, T.; Schulte, D.; Ehses, J.; Kiebler, M.; Hasler, J.; Huttner, H.B.; Vandenbroucke, R.E.; Vandendriessche, C.; et al. Choroid plexus-derived miR-204 regulates the number of quiescent neural stem cells in the adult brain. EMBO J. 2019, 38, e100481. [CrossRef] [PubMed]

107. Delgado, A.C.; Ferrón, S.R.; Vicente, D.; Porlan, E.; Perez-Villalba, A.; Trujillo, C.M.; D’Ocón, P.; Fariñas, I. Endothelial NT-3 delivered by vasculature and CSF promotes quiescence of subependymal neural stem cells through nitric oxide induction. Neuron 2014, 83, 572-585. [CrossRef]

108. Spatazza, J.; Lee, H.H.C.; Di Nardo, A.A.; Tibaldi, L.; Joliot, A.; Hensch, T.K.; Prochiantz, A. Choroid-Plexus-Derived Otx2 Homeoprotein Constrains Adult Cortical Plasticity. Cell Rep. 2013, 3, 1815-1823. [CrossRef]

109. Esteve, P.; Rueda-Carrasco, J.; Inés Mateo, M.; Martin-Bermejo, M.J.; Draffin, J.; Pereyra, G.; Sandonís, Á.; Crespo, I.; Moreno, I.; Aso, E.; et al. Elevated levels of Secreted-Frizzled-Related-Protein 1 contribute to Alzheimer's disease pathogenesis. Nat. Neurosci. 2019, 22, 1258-1268. [CrossRef]

110. Sawamoto, K.; Wichterle, H.; Gonzalez-Perez, O.; Cholfin, J.A.; Yamada, M.; Spassky, N.; Murcia, N.S.; Garcia-Verdugo, J.M.; Marin, O.; Rubenstein, J.L.R.; et al. New Neurons Follow the Flow of Cerebrospinal Fluid in the Adult Brain. Science 2006, 311, 629-632. [CrossRef]

111. Johansson, P.a.; Irmler, M.; Acampora, D.; Beckers, J.; Simeone, A.; Götz, M. The transcription factor Otx2 regulates choroid plexus development and function. Development 2013, 140, 1055-1066. [CrossRef]

112. Kato, M.; Soprano, D.R.; Makover, A.; Kato, K.; Herbert, J.; Goodman, D.S. Localization of immunoreactive transthyretin (prealbumin) and of transthyretin mRNA in fetal and adult rat brain. Differentiation 1986, 31, 228-235. [CrossRef] [PubMed]

113. Moos, T.; Morgan, E.H. Transferrin and Transferrin Receptor Function in Brain Barrier Systems. Cell. Mol. Neurobiol. 2000, 20, 77-95. [CrossRef] [PubMed]

114. Yang, J.; Dombrowski, S.M.; Deshpande, A.; Krajcir, N.; Luciano, M.G. VEGF/VEGFR-2 changes in frontal cortex, choroid plexus, and CSF after chronic obstructive hydrocephalus. J. Neurol. Sci. 2010, 296, 39-46. [CrossRef] [PubMed]

115. Planques, A.; Oliveira Moreira, V.; Dubreuil, C.; Prochiantz, A.; Di Nardo, A.A. OTX2 Signals from the Choroid Plexus to Regulate Adult Neurogenesis. eneuro 2019, 6. [CrossRef] [PubMed]

116. Bernard, C.; Vincent, C.; Testa, D.; Bertini, E.; Ribot, J.; Di Nardo, A.A.; Volovitch, M.; Prochiantz, A. A Mouse Model for Conditional Secretion of Specific Single-Chain Antibodies Provides Genetic Evidence for Regulation of Cortical Plasticity by a Non-cell Autonomous Homeoprotein Transcription Factor. PLOS Genet. 2016, 12, e1006035. [CrossRef]

117. Wang, W.-X.; Fardo, D.W.; Jicha, G.A.; Nelson, P.T. A Customized Quantitative PCR MicroRNA Panel Provides a Technically Robust Context for Studying Neurodegenerative Disease Biomarkers and Indicates a High Correlation Between Cerebrospinal Fluid and Choroid Plexus MicroRNA Expression. Mol. Neurobiol. 2017, 54, 8191-8202. [CrossRef]

118. Shu, P.; Wu, C.; Liu, W.; Ruan, X.; Liu, C.; Hou, L.; Zeng, Y.; Fu, H.; Wang, M.; Chen, P.; et al. The spatiotemporal expression pattern of microRNAs in the developing mouse nervous system. J. Biol. Chem. 2019, 294, 3444-3453. [CrossRef]

119. Cernilogar, F.M.; Di Giaimo, R.; Rehfeld, F.; Cappello, S.; Lie, D.C. RNA interference machinery-mediated gene regulation in mouse adult neural stem cells. BMC Neurosci. 2015, 16, 60. [CrossRef]

120. Grapp, M.; Wrede, A.; Schweizer, M.; Hüwel, S.; Galla, H.-J.; Snaidero, N.; Simons, M.; Bückers, J.; Low, P.S.; Urlaub, H.; et al. Choroid plexus transcytosis and exosome shuttling deliver folate into brain parenchyma. Nat. Commun. 2013, 4, 2123. [CrossRef] 
121. Carro, E.; Spuch, C.; Trejo, J.L.; Antequera, D.; Torres-Aleman, I. Choroid Plexus Megalin Is Involved in Neuroprotection by Serum Insulin-Like Growth Factor I. J. Neurosci. 2005, 25, 10884-10893. [CrossRef]

122. Feliciano, D.M.; Zhang, S.; Nasrallah, C.M.; Lisgo, S.N.; Bordey, A. Embryonic cerebrospinal fluid nanovesicles carry evolutionarily conserved molecules and promote neural stem cell amplification. PLoS ONE 2014, 9, e88810. [CrossRef] [PubMed]

123. Bachy, I.; Kozyraki, R.; Wassef, M. The particles of the embryonic cerebrospinal fluid: How could they influence brain development? Brain Res. Bull. 2008, 75, 289-294. [CrossRef] [PubMed]

124. Kalluri, R.; LeBleu, V.S. The biology, function, and biomedical applications of exosomes. Science 2020, 367, eaau6977. [CrossRef] [PubMed]

125. Ciregia, F.; Urbani, A.; Palmisano, G. Extracellular Vesicles in Brain Tumors and Neurodegenerative Diseases. Front. Mol. Neurosci. 2017, 10, 276. [CrossRef] [PubMed]

126. Thompson, A.G.; Gray, E.; Mager, I.; Fischer, R.; Thézénas, M.-L.; Charles, P.D.; Talbot, K.; El Andaloussi, S.; Kessler, B.M.; Wood, M.; et al. UFLC-Derived CSF Extracellular Vesicle Origin and Proteome. Proteomics 2018, 18, 1800257. [CrossRef] [PubMed]

127. Dos Santos, M.C.T.; Barreto-Sanz, M.A.; Correia, B.R.S.; Bell, R.; Widnall, C.; Perez, L.T.; Berteau, C.; Schulte, C.; Scheller, D.; Berg, D.; et al. miRNA-based signatures in cerebrospinal fluid as potential diagnostic tools for early stage Parkinson's disease. Oncotarget 2018, 9, 17455. [CrossRef]

128. Raoof, R.; Jimenez-Mateos, E.M.; Bauer, S.; Tackenberg, B.; Rosenow, F.; Lang, J.; Onugoren, M.D.; Hamer, H.; Huchtemann, T.; Körtvélyessy, P.; et al. Cerebrospinal fluid microRNAs are potential biomarkers of temporal lobe epilepsy and status epilepticus. Sci. Rep. 2017, 7, 3328. [CrossRef]

129. Tietje, A.; Maron, K.N.; Wei, Y.; Feliciano, D.M. Cerebrospinal Fluid Extracellular Vesicles Undergo Age Dependent Declines and Contain Known and Novel Non-coding RNAs. PLoS ONE 2014, 9, e113116. [CrossRef]

130. Coulter, M.E.; Dorobantu, C.M.; Lodewijk, G.A.; Delalande, F.; Cianferani, S.; Ganesh, V.S.; Smith, R.S.; Lim, E.T.; Xu, C.S.; Pang, S.; et al. The ESCRT-III Protein CHMP1A Mediates Secretion of Sonic Hedgehog on a Distinctive Subtype of Extracellular Vesicles. Cell Rep. 2018, 24, 973-986.e8. [CrossRef]

131. O’Hara, B.A.; Morris-Love, J.; Gee, G.V.; Haley, S.A.; Atwood, W.J. JC Virus infected choroid plexus epithelial cells produce extracellular vesicles that infect glial cells independently of the virus attachment receptor. PLOS Pathog. 2020, 16, e1008371. [CrossRef]

132. Kwon, Y.; Nukala, S.B.; Srivastava, S.; Miyamoto, H.; Ismail, N.I.; Ong, S.-B.; Lee, W.H.; Ong, S.-G. Exosomes Facilitate Transmission of SARS-CoV-2 Genome into Human Induced Pluripotent Stem Cell-Derived Cardiomyocytes. bioRxiv 2020. [CrossRef]

133. Paniz-Mondolfi, A.; Bryce, C.; Grimes, Z.; Gordon, R.E.; Reidy, J.; Lednicky, J.; Sordillo, E.M.; Fowkes, M. Central Nervous System Involvement by Severe Acute Respiratory Syndrome Coronavirus -2 (SARS-CoV-2). J. Med. Virol. 2020, 92, 699-702. [CrossRef] [PubMed]

134. Moriguchi, T.; Harii, N.; Goto, J.; Harada, D.; Sugawara, H.; Takamino, J.; Ueno, M.; Sakata, H.; Kondo, K.; Myose, N.; et al. A first case of meningitis/encephalitis associated with SARS-Coronavirus-2. Int. J. Infect. Dis. 2020, 94, 55-58. [CrossRef] [PubMed]

135. Chen, R.; Wang, K.; Yu, J.; Howard, D.; French, L.; Chen, Z.; Wen, C.; Xu, Z. The spatial and cell-type distribution of SARS-CoV-2 receptor ACE2 in human and mouse brain. bioRxiv 2020. [CrossRef]

136. Wang, H.; Eckel, R.H. What are lipoproteins doing in the brain? Trends Endocrinol. Metab. 2014, $25,8-14$. [CrossRef] [PubMed]

137. Feingold, K.R.; Grunfeld, C. Introduction to Lipids and Lipoproteins. In Endotext; eingold, K.R., Anawalt, B., Boyce, A., Chrousos, G., Dungan, K., Grossman, A., Hershman, J.M., Kaltsas, G., Koch, C., Kopp, P., Eds.; South Dartmouth (MA): Dartmouth, MA, USA, 2018.

138. Kuai, R.; Li, D.; Chen, Y.E.; Moon, J.J.; Schwendeman, A. High-Density Lipoproteins: Nature's Multifunctional Nanoparticles. ACS Nano 2016, 10, 3015-3041. [CrossRef] [PubMed]

139. Ladu, M.J.O.; Reardon, C.; Van Eldik, L.; Fagan, A.M.; BU, G.; Holtzman, D.; Getz, G.S. Lipoproteins in the Central Nervous System. Ann. N. Y. Acad. Sci. 2006, 903, 167-175. [CrossRef]

140. LaDu, M.J.; Gilligan, S.M.; Lukens, J.R.; Cabana, V.G.; Reardon, C.A.; Van Eldik, L.J.; Holtzman, D.M. Nascent Astrocyte Particles Differ from Lipoproteins in CSF. J. Neurochem. 1998, 70, 2070-2081. [CrossRef] 
141. Marques, F.; Sousa, J.C.; Coppola, G.; Gao, F.; Puga, R.; Brentani, H.; Geschwind, D.H.; Sousa, N.; Correia-Neves, M.; Palha, J.A. Transcriptome signature of the adult mouse choroid plexus. Fluids Barriers CNS 2011, 8, 10. [CrossRef]

142. Koch, M.; Furtado, J.D.; Falk, K.; Leypoldt, F.; Mukamal, K.J.; Jensen, M.K. Apolipoproteins and their subspecies in human cerebrospinal fluid and plasma. Alzheimer's Dement. Diagnosis, Assess. Dis. Monit. 2017, 6, 182-187. [CrossRef]

143. Vance, J.E.; Hayashi, H. Formation and function of apolipoprotein E-containing lipoproteins in the nervous system. Biochim. Biophys. Acta-Mol. Cell Biol. Lipids 2010, 1801, 806-818. [CrossRef]

144. Fujiyoshi, M.; Ohtsuki, S.; Hori, S.; Tachikawa, M.; Terasaki, T. 24S-hydroxycholesterol induces cholesterol release from choroid plexus epithelial cells in an apical- and apoE isoform-dependent manner concomitantly with the induction of ABCA1 and ABCG1 expression. J. Neurochem. 2007, 100, 968-978. [CrossRef] [PubMed]

145. Tachikawa, M.; Watanabe, M.; Hori, S.; Fukaya, M.; Ohtsuki, S.; Asashima, T.; Terasaki, T. Distinct spatio-temporal expression of ABCA and ABCG transporters in the developing and adult mouse brain. J. Neurochem. 2005, 95, 294-304. [CrossRef] [PubMed]

146. Parada, C.; Gato, Á.; Bueno, D. Mammalian embryonic cerebrospinal fluid proteome has greater apolipoprotein and enzyme pattern complexity than the avian proteome. J. Proteome Res. 2005, 4, 2420-2428. [CrossRef] [PubMed]

147. Flowers, S.A.; Grant, O.C.; Woods, R.J.; Rebeck, G.W. O-glycosylation on cerebrospinal fluid and plasma apolipoprotein E differs in the lipid-binding domain. Glycobiology 2019, 30, 74-85. [CrossRef] [PubMed]

148. Parada, C.; Escolà-Gil, J.C.; Bueno, D. Low-density lipoproteins from embryonic cerebrospinal fluid are required for neural differentiation. J. Neurosci. Res. 2008, 86, 2674-2684. [CrossRef] [PubMed]

149. Bahrami, A.; Barreto, G.E.; Lombardi, G.; Pirro, M.; Sahebkar, A. Emerging roles for high-density lipoproteins in neurodegenerative disorders. BioFactors 2019, 45, 725-739. [CrossRef] [PubMed]

150. Palm, W.; Swierczynska, M.M.; Kumari, V.; Ehrhart-Bornstein, M.; Bornstein, S.R.; Eaton, S. Secretion and Signaling Activities of Lipoprotein-Associated Hedgehog and Non-Sterol-Modified Hedgehog in Flies and Mammals. PLoS Biol. 2013, 11. [CrossRef]

151. Natalya, A.; Alexey, T.; Evgueni, S.; Christian, H. Low Density Lipoproteins Interact With Acidic Fibroblast Growth Factor and Modify Its Function. Arterioscler. Thromb. Vasc. Biol. 2003, 23, 601-607. [CrossRef]

152. Raha-Chowdhury, R.; Henderson, J.W.; Raha, A.A.; Vuono, R.; Bickerton, A.; Jones, E.; Fincham, R.; Allinson, K.; Holland, A.; Zaman, S.H. Choroid Plexus Acts as Gatekeeper for TREM2, Abnormal Accumulation of ApoE, and Fibrillary Tau in Alzheimer's Disease and in Down Syndrome Dementia. J. Alzheimers. Dis. 2019, 69, 91-109. [CrossRef]

153. Yeh, F.L.; Wang, Y.; Tom, I.; Gonzalez, L.C.; Sheng, M. TREM2 Binds to Apolipoproteins, Including APOE and CLU/APOJ, and Thereby Facilitates Uptake of Amyloid-Beta by Microglia. Neuron 2016, 91, 328-340. [CrossRef] [PubMed]

154. Vickers, K.C.; Palmisano, B.T.; Shoucri, B.M.; Shamburek, R.D.; Remaley, A.T. MicroRNAs are transported in plasma and delivered to recipient cells by high-density lipoproteins. Nat. Cell Biol. 2011, 13, 423-433. [CrossRef]

155. Mihara, E.; Hirai, H.; Yamamoto, H.; Tamura-Kawakami, K.; Matano, M.; Kikuchi, A.; Sato, T.; Takagi, J. Active and water-soluble form of lipidated Wnt protein is maintained by a serum glycoprotein afamin/ $\alpha$-albumin. Elife 2016, 5. [CrossRef] [PubMed]

156. Jerkovic, L.; Voegele, A.F.; Chwatal, S.; Kronenberg, F.; Radcliffe, C.M.; Wormald, M.R.; Lobentanz, E.M.; Ezeh, B.; Eller, P.; Dejori, N.; et al. Afamin Is a Novel Human Vitamin E-Binding Glycoprotein Characterization and In Vitro Expression. J. Proteome Res. 2005, 4, 889-899. [CrossRef] [PubMed]

157. Nakato, H.; Li, J.-P. Chapter Seven-Functions of Heparan Sulfate Proteoglycans in Development: Insights From Drosophila Models. In International Review of Cell and Molecular Biology; Academic Press: Cambridge, MA, USA; Volume 325, pp. 275-293. ISBN 1937-6448.

158. Cartier, L.; García, L.; Kettlun, A.M.; Castañeda, P.; Collados, L.; Va'squez, F.; Giraudon, P.; Belin, M.F.; Valenzuela, M.A. Extracellular matrix protein expression in cerebrospinal fluid from patients with tropical spastic paraparesis associated with HTLV-I and Creutzfeldt-Jakob disease. Scand. J. Clin. Lab. Invest. 2004, 64, 101-107. [CrossRef] [PubMed] 
159. Lugert, S.; Kremer, T.; Jagasia, R.; Herrmann, A.; Aigner, S.; Giachino, C.; Mendez-David, I.; Gardier, A.M.; Carralot, J.P.; Meistermann, H.; et al. Glypican-2 levels in cerebrospinal fluid predict the status of adult hippocampal neurogenesis. Sci. Rep. 2017, 7, 46543. [CrossRef]

160. Eugster, C.; Panáková, D.; Mahmoud, A.; Eaton, S. Lipoprotein-Heparan Sulfate Interactions in the Hh Pathway. Dev. Cell 2007, 13, 57-71. [CrossRef]

161. Elliott, D.A.; Weickert, C.S.; Garner, B. Apolipoproteins in the brain: Implications for neurological and psychiatric disorders. Clin. Lipidol. 2010, 5, 555-573. [CrossRef]

162. Safina, D.; Schlitt, F.; Romeo, R.; Pflanzner, T.; Pietrzik, C.U.; Narayanaswami, V.; Edenhofer, F.; Faissner, A. Low-density lipoprotein receptor-related protein 1 is a novel modulator of radial glia stem cell proliferation, survival, and differentiation. Glia 2016, 64, 1363-1380. [CrossRef]

163. Rauch, J.N.; Luna, G.; Guzman, E.; Audouard, M.; Challis, C.; Sibih, Y.E.; Leshuk, C.; Hernandez, I.; Wegmann, S.; Hyman, B.T.; et al. LRP1 is a master regulator of tau uptake and spread. Nature 2020, 580, 381-385. [CrossRef]

164. Drews, A.; De, S.; Flagmeier, P.; Wirthensohn, D.C.; Chen, W.-H.; Whiten, D.R.; Rodrigues, M.; Vincke, C.; Muyldermans, S.; Paterson, R.W.; et al. Inhibiting the Ca(2+) Influx Induced by Human CSF. Cell Rep. 2017, 21, 3310-3316. [CrossRef] [PubMed]

165. Golabek, A.; Marques, M.A.; Lalowski, M.; Wisniewski, T. Amyloid $\beta$ binding proteins in vitro and in normal human cerebrospinal fluid. Neurosci. Lett. 1995, 191, 79-82. [CrossRef]

166. Johansson, P.; Almqvist, E.G.; Bjerke, M.; Wallin, A.; Johansson, J.O.; Andreasson, U.; Blennow, K.; Zetterberg, H.; Svensson, J. Reduced Cerebrospinal Fluid Concentration of Apolipoprotein A-I in Patients with Alzheimer's Disease. J. Alzheimer's Dis. 2017, 59, 1017-1026. [CrossRef] [PubMed]

167. Fernández-de Retana, S.; Montañola, A.; Marazuela, P.; De La Cuesta, M.; Batlle, A.; Fatar, M.; Grudzenski, S.; Montaner, J.; Hernández-Guillamon, M. Intravenous treatment with human recombinant ApoA-I Milano reduces beta amyloid cerebral deposition in the APP23-transgenic mouse model of Alzheimer's disease. Neurobiol. Aging 2017, 60, 116-128. [CrossRef]

168. Gato, A.; Alonso, M.I.; Lamus, F.; Miyan, J. Neurogenesis: A process ontogenically linked to brain cavities and their content, CSF. Semin. Cell Dev. Biol. 2020, 102, 21-27. [CrossRef]

169. Stiles, J.; Jernigan, T.L. The Basics of Brain Development. Neuropsychol. Rev. 2010, 20, 327-348. [CrossRef]

170. Gato, Á.; Moro, J.A.; Alonso, M.I.; Bueno, D.; De La Mano, A.; Martín, C. Embryonic cerebrospinal fluid regulates neuroepithelial survival, proliferation, and neurogenesis in chick embryos. Anat. Rec. Part A Discov. Mol. Cell. Evol. Biol. 2005, 284, 475-484. [CrossRef]

171. Yeh, C.; Li, A.; Chuang, J.-Z.; Saito, M.; Cáceres, A.; Sung, C.-H. IGF-1 Activates a Cilium-Localized Noncanonical G $\beta \gamma$ Signaling Pathway that Regulates Cell-Cycle Progression. Dev. Cell 2013, 26, 358-368. [CrossRef] [PubMed]

172. Saade, M.; Gonzalez-Gobartt, E.; Escalona, R.; Usieto, S.; Martí, E. Shh-mediated centrosomal recruitment of PKA promotes symmetric proliferative neuroepithelial cell division. Nat. Cell Biol. 2017, 19, 493-503. [CrossRef]

173. Tiberi, L.; Vanderhaeghen, P.; van den Ameele, J. Cortical neurogenesis and morphogens: Diversity of cues, sources and functions. Curr. Opin. Cell Biol. 2012, 24, 269-276. [CrossRef]

174. Gonçalves, J.T.; Schafer, S.T.; Gage, F.H. Adult Neurogenesis in the Hippocampus: From Stem Cells to Behavior. Cell 2016, 167, 897-914. [CrossRef]

175. Capilla-Gonzalez, V.; Herranz-Pérez, V.; García-Verdugo, J.M. The aged brain: Genesis and fate of residual progenitor cells in the subventricular zone. Front. Cell. Neurosci. 2015, 9, 365. [CrossRef] [PubMed]

176. Mirzadeh, Z.; Merkle, F.T.; Soriano-Navarro, M.; Garcia-Verdugo, J.M.; Alvarez-Buylla, A. Neural Stem Cells Confer Unique Pinwheel Architecture to the Ventricular Surface in Neurogenic Regions of the Adult Brain. Cell Stem Cell 2008, 3, 265-278. [CrossRef] [PubMed]

177. Hu, X.-L.; Chen, G.; Zhang, S.; Zheng, J.; Wu, J.; Bai, Q.-R.; Wang, Y.; Li, J.; Wang, H.; Feng, H.; et al. Persistent Expression of VCAM1 in Radial Glial Cells Is Required for the Embryonic Origin of Postnatal Neural Stem Cells. Neuron 2017, 95, 309-325. [CrossRef] [PubMed]

178. Gregg, C.; Weiss, S. CNTF/LIF/gp130 receptor complex signaling maintains a VZ precursor differentiation gradient in the developing ventral forebrain. Development 2005, 132, 565-578. [CrossRef] 
179. Mizrak, D.; Levitin, H.M.; Delgado, A.C.; Crotet, V.; Yuan, J.; Chaker, Z.; Silva-Vargas, V.; Sims, P.A.; Doetsch, F. Single-Cell Analysis of Regional Differences in Adult V-SVZ Neural Stem Cell Lineages. Cell Rep. 2019, 26, 394-406. [CrossRef]

180. Mizrak, D.; Bayin, N.S.; Yuan, J.; Liu, Z.; Suciu, R.M.; Niphakis, M.J.; Ngo, N.; Lum, K.M.; Cravatt, B.F.; Joyner, A.L.; et al. Single-Cell Profiling and SCOPE-Seq Reveal Lineage Dynamics of Adult Ventricular-Subventricular Zone Neurogenesis and NOTUM as a Key Regulator. Cell Rep. 2020, 31, 107805. [CrossRef]

181. Vancamp, P.; Gothié, J.-D.; Luongo, C.; Sébillot, A.; Le Blay, K.; Butruille, L.; Pagnin, M.; Richardson, S.J.; Demeneix, B.A.; Remaud, S. Gender-specific effects of transthyretin on neural stem cell fate in the subventricular zone of the adult mouse. Sci. Rep. 2019, 9, 19689. [CrossRef]

182. Quintela, T.; Gonçalves, I.; Carreto, L.C.; Santos, M.A.S.; Marcelino, H.; Patriarca, F.M.; Santos, C.R.A. Analysis of the Effects of Sex Hormone Background on the Rat Choroid Plexus Transcriptome by cDNA Microarrays. PLoS ONE 2013, 8, e60199. [CrossRef]

183. Hildebrandt, S.; Schmidt, A.; Stoll, A.; Schmitt, O.; Köhling, R.; Wree, A.; Haas, S.J.-P.; Pützer, B.M. Targeting of neural stem cells in the hippocampus of adult rats by custom-made Ad vectors. Brain Struct. Funct. 2010, 215, 105-113. [CrossRef]

184. Reetz, J.; Hildebrandt, S.; Schmidt, A.; Meier, C.; Herchenröder, O.; Gläser, A.; Witt, M.; Pützer, B.M.; Wree, A. Novel subventricular zone early progenitor cell-specific adenovirus for in vivo therapy of central nervous system disorders reinforces brain stem cell heterogeneity. Brain Struct. Funct. 2016, 221, 2049-2059. [CrossRef] [PubMed]

185. Gajera, C.R.; Emich, H.; Lioubinski, O.; Christ, A.; Beckervordersandforth-Bonk, R.; Yoshikawa, K.; Bachmann, S.; Christensen, E.I.; Götz, M.; Kempermann, G.; et al. LRP2 in ependymal cells regulates BMP signaling in the adult neurogenic niche. J. Cell Sci. 2010, 123, 1922-1930. [CrossRef] [PubMed]

186. Zywitza, V.; Misios, A.; Bunatyan, L.; Willnow, T.E.; Rajewsky, N. Single-Cell Transcriptomics Characterizes Cell Types in the Subventricular Zone and Uncovers Molecular Defects Impairing Adult Neurogenesis. Cell Rep. 2018, 25. [CrossRef] [PubMed]

187. Chen, X.; He, Y.; Tian, Y.; Wang, Y.; Wu, Z.; Lan, T.; Wang, H.; Cheng, K.; Xie, P. Different Serotypes of Adeno-Associated Virus Vector- and Lentivirus-Mediated Tropism in Choroid Plexus by Intracerebroventricular Delivery. Hum. Gene Ther. 2020, 31, 440-447. [CrossRef]

188. Regev, L.; Ezrielev, E.; Gershon, E.; Gil, S.; Chen, A. Genetic approach for intracerebroventricular delivery. Proc. Natl. Acad. Sci. USA 2010, 107, 4424-4429. [CrossRef]

189. Zheng, M.; Huang, M.; Ma, X.; Chen, H.; Gao, X. Harnessing Exosomes for the Development of Brain Drug Delivery Systems. Bioconjug. Chem. 2019, 30, 994-1005. [CrossRef]

190. Zhu, C.; Xia, Y. Biomimetics: Reconstitution of low-density lipoprotein for targeted drug delivery and related theranostic applications. Chem. Soc. Rev. 2017, 46, 7668-7682. [CrossRef]

191. Clevers, H. Modeling Development and Disease with Organoids. Cell 2016, 165, 1586-1597. [CrossRef]

192. Pellegrini, L.; Bonfio, C.; Chadwick, J.; Begum, F.; Skehel, M.; Lancaster, M.A. Human CNS barrier-forming organoids with cerebrospinal fluid production. Science 2020, eaaz5626. [CrossRef]

193. Renner, M.; Lancaster, M.A.; Bian, S.; Choi, H.; Ku, T.; Peer, A.; Chung, K.; Knoblich, J.A. Self-organized developmental patterning and differentiation in cerebral organoids. EMBO J. 2017, 36, 1316-1329. [CrossRef]

194. Hochstetler, A.E.; Whitehouse, L.; Antonellis, P.; Berbari, N.F.; Blazer-Yost, B.L. Characterizing the Expression of TRPV4 in the Choroid Plexus Epithelia as a Prospective Component in the Development of Hydrocephalus in the Gas8GT Juvenile Mouse Model. FASEB J. 2018, 32, 750.12. [CrossRef]

195. Allocco, A.A.; Jin, S.C.; Duy, P.Q.; Furey, C.G.; Zeng, X.; Dong, W.; Nelson-Williams, C.; Karimy, J.K.; DeSpenza, T.; Hao, L.T.; et al. Recessive Inheritance of Congenital Hydrocephalus With Other Structural Brain Abnormalities Caused by Compound Heterozygous Mutations in ATP1A3. Front. Cell. Neurosci. 2019, 13, 425. [CrossRef] [PubMed]

(C) 2020 by the authors. Licensee MDPI, Basel, Switzerland. This article is an open access article distributed under the terms and conditions of the Creative Commons Attribution (CC BY) license (http://creativecommons.org/licenses/by/4.0/). 